\title{
Ocupación paleoindia en el centro-norte de Chile: Adaptación circunlacustre en las tierras bajas
}

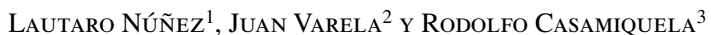

\section{Introducción}

Este informe es el resultado de labores multidisciplinarias apoyadas por la National Geographic Society Foundation y el Programa Paleoindio del Smithsonian Institution de Washington, destinadas a reconstruir las relaciones entre ocupaciones humanas tempranas y la variabilidad ambiental-faunística durante el Pleistoceno Superior-Holoceno en Chile. ${ }^{4}$ Los autores han reunido la información más pertinente en torno a los sitios de Tagua Tagua y Quereo, con el fin de ordenar ciertas hipótesis de trabajo en torno a futuras ampliaciones de las investigaciones. ${ }^{5}$ Para este efecto

1 Instituto de Investigaciones Arqueológicas, Universidad del Norte, San Pedro de Atacama, CHILE.

2 Departamento de Geología y Geofísica, Universidad de Chile, Santiago, CHILE.

3 Centro de Investigaciones Científicas de Río Negro, Viedma, ARGENTINA.

4 Durante el año 1985 se reiniciaron las labores en Tagua Tagua con una campaña de calicatas que permitió ubicar un segundo yacimiento (Tagua Tagua 2). Al equipo compuesto por L. Núñez, J. Varela y R. Casamiquela se han sumado los investigadores H. Niemeyer y V. Schiappacasse.

5 Los antecedentes iniciales que dieron cuenta del potencial paleontológico de los sitios de Quereo y Tagua Tagua provienen del siglo pasado y comienzo del presente. En el primer caso se da cuenta del hallazgo de mastodonte en Los Vilos (Quereo), de acuerdo a la información de Sundt (1903). En Tagua Tagua se conocen numerosos hallazgos de mastodontes ubicados en sus depósitos, de los cuales dan cuenta los trabajos de Gay (1848, 1854), Domeyko (1868), Schneider $(1926,1927)$ y Latcham (1929). Las características que presentaba la antigua laguna de Tagua Tagua en tiempos históricos son conocidas a través de las descripciones de diferentes naturalistas e historiadores que tuvieron la oportunidad de visitarla antes de su desecamiento. Entre estos autores se pueden mencionar a Molina (Gunkel 1967), Gay (1848, 1854), Darwin (1882) y Domeyko (1868). De acuerdo a dichas descripciones, la laguna tenía una figura elíptica de unos $30 \mathrm{~km}^{2}$ de superficie, con una profundidad máxima de $5 \mathrm{~m}$. Estaba poblada por una abundante fauna de peces y aves, y presentaba una nutrida vegetación acuática costera. Esta última desarrollaba en el borde de la laguna especies de esteras enraizadas en forma de zócalos o voladizos, los cuales se fragmentaban dando lugar a las islas flotantes denominadas localmente "chivines". La laguna fue desecada el año 1841 por medio de un canal de orientaron su atención en la denominada laguna de Tagua Tagua, que corresponde a una "rinconada" del borde oriental de la cordillera de la Costa, ocupada hasta el año 1841 por un depósito de agua. Esta se ubica en el departamento de San Vicente de Tagua Tagua, provincia de O'Higgins, a unos $120 \mathrm{~km}$ al suroeste de Santiago y a unos $20 \mathrm{~km}$ al noroeste de San Fernando (Figura 1), siendo sus coordenadas geográficas $34^{\circ} 30^{\prime}$ Lat. S y $71^{\circ} 10^{\prime}$ Long. O.

Los primeros antecedentes corresponden a una indagación multidisciplinaria llevada a a cabo por un amplio grupo de investigadores en la zona de Tagua Tagua, en la cual se logró caracterizar algunos indicadores paleontológicos y arqueológicos ocurrentes durante el Cuaternario Superior (Casamiquela et al. 1967; Montané 1967; Casamiquela 1976). El estudio estratigráfico-sedimentológico, como parte de esta investigación, estableció una columna estratigráfica de los depósitos y sirvió de control y referencia a las diferentes indagaciones realizadas (Varela 1976). Paralelamente se estableció una secuencia cronológica de los principales eventos ocurridos en la laguna y su incidencia en la reconstitución de la historia geológica del Cuaternario Superior de Chile Central.

El trabajo de Varela (1976) consistió en un reconocimiento de los afloramientos de los rellenos de la

drenaje ubicado en su extremo norte, el cual dirigió sus aguas hacia el valle del estero Zamorano. Al momento de excavarse dicho canal y en diversas oportunidades después, se han recolectado restos fósiles de mastodontes y otros vertebrados. Según Schneider (1927), hasta esa fecha se habían extraído restos correspondientes a 12 mastodontes. De no haber ocurrido esta desecación no se habrían registrado las primeras evidencias paleoindias que sustentan estas investigaciones. Los autores agradecen el apoyo recibido de sus instituciones, del Smithsonian Institution, Ilustre Municipalidad de San Vicente de Tagua Tagua, y de los señores Augusto Rodríguez Ruiz de Gamboa, alcalde de la corporación; Luis Costabal y Luis Núñez, propietarios de los predios involucrados. A Iván Cáceres, arqueólogo asistente y conocedor de la región, quien se incorporó a las labores del preproyecto en curso. 




Figura 1. Ubicación de la laguna de Tagua Tagua. 
cuenca lacustre, y en el levantamiento de dos columnas estratigráficas denominadas, respectivamente, Columna Estratigráfica 1 "Excavación" y Columna Estratigráfica 2 "Represa". Estas columnas se ubican en el extremo norte del canal principal que drena la cuenca de Tagua Tagua hacia el estero Zamorano (Figura 2). Ambas columnas se sitúan en el corte del margen izquierdo del canal, la primera de ellas, con un espesor total de $10.73 \mathrm{~m}$, fue levantada $100 \mathrm{~m}$ agua arriba de la represa que contiene las aguas del canal, en el mismo sitio en que se realizaban las excavaciones arqueológicas. La segunda columna, con un espesor total de $18 \mathrm{~m}$, se levantó $15 \mathrm{~m}$ aguas abajo de la mencionada represa. De estas columnas se extrajeron un total de 107 muestras, las cuales fueron procesadas y estudiadas en el Laboratorio de Sedimentología del Departamento de Geología de la Universidad de Chile (Varela 1976b).

Las excavaciones arqueológicas que motivaron este encuentro multidisciplinario estuvieron a cargo de Montané $(1967,1968)$ y se limitaron al control de dos niveles de ocupación: un nivel superior o arcaico datado en el VI milenio AP (Montané 1969; Durán 1980) y de un nivel inferior paleoindio datado en el XI milenio AP, presente en varios cuadrantes localizados en el borde izquierdo del barranco que limita con el canal de desagüe (ver Figura 2). Montané aplicó técnicas de decapado, incluyendo los registros de evidencias in situ, con la colaboración de J. Palma (1969) y la participación de los coautores de este artículo, tanto en lo referente al análisis geológico como paleontológico. Aunque Montané no ha publicado la documentación del sitio, su excavación permitió constatar una asociación estricta entre industria lítica y ósea junto a vertebrados pleistocénicos, en especial en torno al contexto de un mastodonte faenado en el lugar mismo del hallazgo.

Nosotros hemos fijado nuestro interés en el ámbito de la desembocadura de la quebrada de Quereo (31 '55'44”' Lat. S, 71³0'43" Long. O), que abarca una zona comprendida entre la bahía de Los Vilos por el norte, la Ensenada El Negro por el sur, el barranco de la cordillera de la Costa al este y el océano Pacífico por el oeste (Figura 3). A esta zona se ingresa a través del camino secundario que entronca la carretera Panamericana con Los Vilos, y que continúa desde este puerto, $2.5 \mathrm{kms}$ hacia el sur, contactando con el sector de la desembocadura de quebrada Quereo. Estudios preliminares de Montané y Bahamondes (1973) habían sugerido una ocupación paleoindio después de controlar una trinchera de inspección de estratos. Los trabajos de campo llevados a cabo por nosotros en la zona se realizaron en septiembre de 1975, mayo, junio y julio de 1977, y noviembre y diciembre de 1978.

Con estos antecedentes y a la luz de nuestra información, deseamos evaluar los episodios de Tagua Tagua y Quereo, con el fin de ordenar un marco de referencia que nos permita una mejor orientación de los próximos proyectos interdisciplinarios en torno a ocupaciones humanas del Pleistoceno Tardío de Chile.

\section{Antecedentes geológicos y geomorfológicos de Tagua Tagua}

La cuenca de Tagua Tagua corresponde al tipo de relieve denominado comúnmente "rinconada", en la región central de Chile. Aquí se situó la laguna homónima (Figura 4), limitada por el desarrollo de un cordón montañoso en forma de semicírculo o anfiteatro ubicado en la margen oriental de la cordillera de la Costa, el cual encierra una zona plana de unos $80 \mathrm{~km}^{2}$ de superficie, la cual se conecta casi a nivel a través del corredor de Cuchipuy con los rellenos del valle longitudinal. Este cordón montañoso se encuentra prácticamente aislado por amplios valles, de los restantes relieves de la cordillera de la Costa: al norte, está limitado por los valles del estero Zamorano y el río Cachapoal; al oriente, por el valle longitudinal, y al sur y occidente, por el valle del río Tinguiririca. Las alturas máximas de este cordón montañoso, en su tramo septentrional, están comprendidas entre 400 y 700 m.snm; en los tramos occidental y sur están comprendidas entre 800 y 1300 m.snm. La superficie plana interior queda claramente delimitada a su vez por la cota 200 m.snm, con una altura mínima ubicada en su sector central de 193 m.snm (Varela 1978).

La línea de altas cumbres que rodea la cuenca encierra una hoya hidrográfica con una superficie total de $240 \mathrm{~km}^{2}$. Esta hoya está surcada por numerosas quebradas pequeñas con saltos, que nacen de la línea de altas cumbres, desembocando en la superficie plana inferior. Estas quebradas tienen una alimentación invernal, entregando sus aguas al canal colector principal que surca el sector central-norte de la planicie, drenando las aguas de la cuenca hacia el valle del estero Zamorano.

El relieve que rodea la cuenca está constituido por rocas estratificadas volcánicas y sedimentarias de 


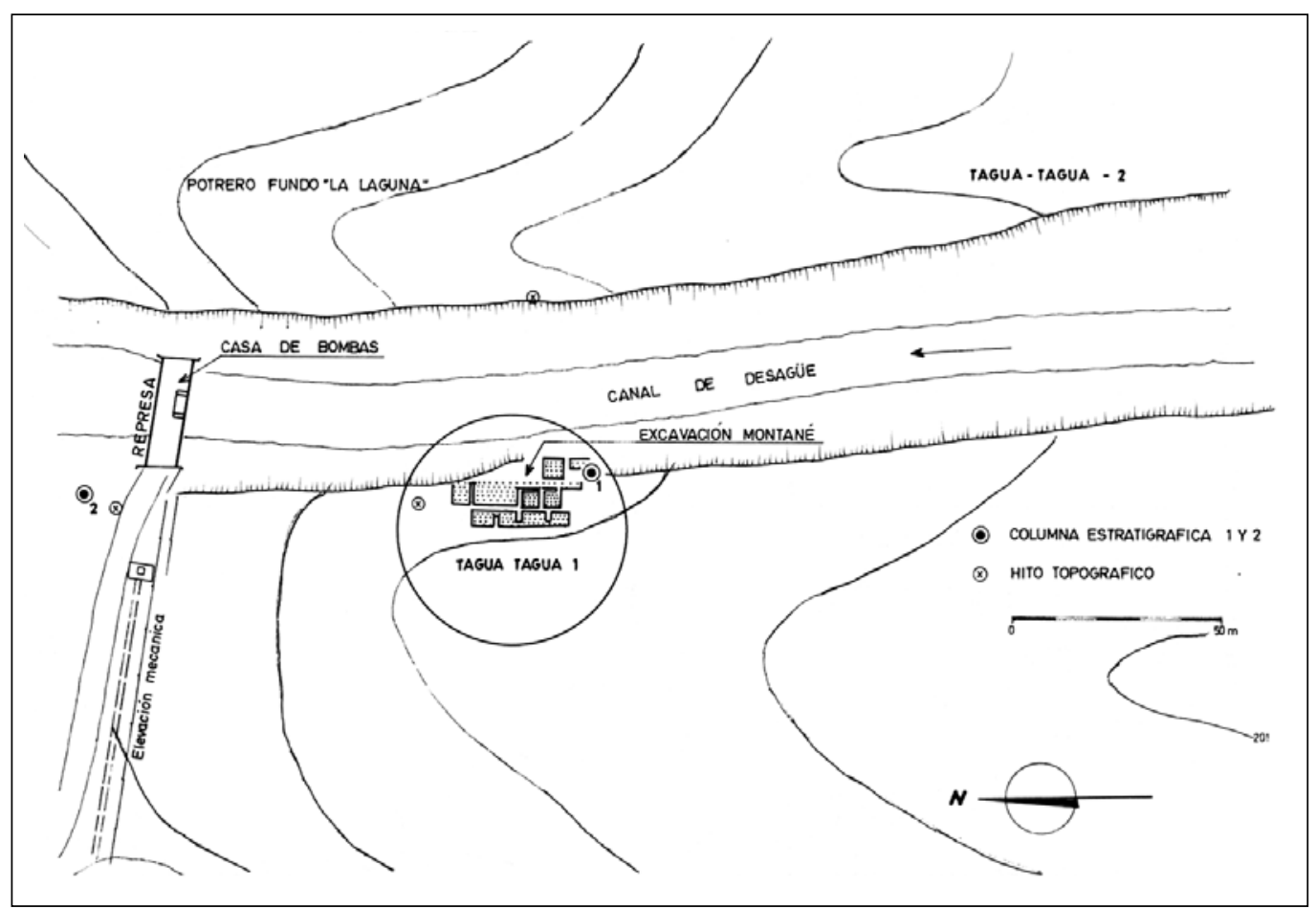

Figura 2. Ubicación de las columnas estratográficas 1 y 2 (Varela 1976) y de la excavación de Montané (1967, 1968) en Tagua Tagua.

edades Jurásico Superior-Cretácico Inferior, las cuales representan $70 \%$ a $80 \%$ de los afloramientos, y por cuerpos ígneos intrusivos de edades cretácicas y terciarias, los cuales representan $20 \%$ a $30 \%$ de la superficie de afloramientos.

La tectónica que afecta estas unidades se caracteriza por el desarrollo de tres sistemas de fallas, los cuales dan lugar a una tectónica de bloques. Estos tres sistemas corresponden a: sistema de rumbos comprendidos entre norte $30^{\circ}$ este y norte $40^{\circ}$ este, con valores más frecuentes en norte $38^{\circ}$ este; sistema de rumbos variables entre norte $5^{\circ}$ oeste y norte $15^{\circ}$ oeste, con valores más frecuentes en norte $10^{\circ}$ oeste; y sistemas de rumbos comprendidos entre norte $55^{\circ}$ oeste y norte $67^{\circ}$ oeste.

Los rasgos geomorfológicos principales del relieve de esta laguna corresponden, por una parte, al cordón de cerros que rodea, y constituye la roca fundamental de la cuenca y, por otra, a la superficie plana originada por los rellenos de la cuenca.

Estos rellenos están integrados por: a) depósitos de cenizas pumicíticas y gravas cineríticas con piedras pómez, las cuales constituyen la parte inferior del relleno reconocido en la cuenca; b) depósitos lacustres de sedimentos finos arcilloso-limosos en parte carbonosos y diatomáceos, que constituyen la parte superior del relleno de la cuenca. Estos se depositaron durante la existencia de la laguna; c) abanicos aluvionales con sedimentos gruesos mal seleccionados y de origen fluvial-torrencial que ocupan el interior de las "rinconadas" menores de la cuenca; d) conos coluviales y escombros de falda con sedimentos gruesos más seleccionados, que forman conos de fuerte pendiente, los cuales se unen en parte para formar franjas continuas al pie de los relieves laterales de la cuenca. Estos materiales han sido originados por procesos gravitatorios.

El cordón de cerros que rodea la cuenca constituye una "rinconada", la cual forma parte de la línea de "rinconadas" del borde oriental de la cordillera de la Costa de Chile Central. El origen de éstas ha sido interpretado como tectónico por Bruggen (1950), mientras que Borde (1966) es partidario de un origen erosivo para este tipo de relieve.

En el caso de Tagua Tagua, el origen de esta "rinconada" ha sido interpretado por Varela (1976) como una fosa tectónica causada por una falla interior de 




Figura 3. Ubicación de la quebrada Quereo. 


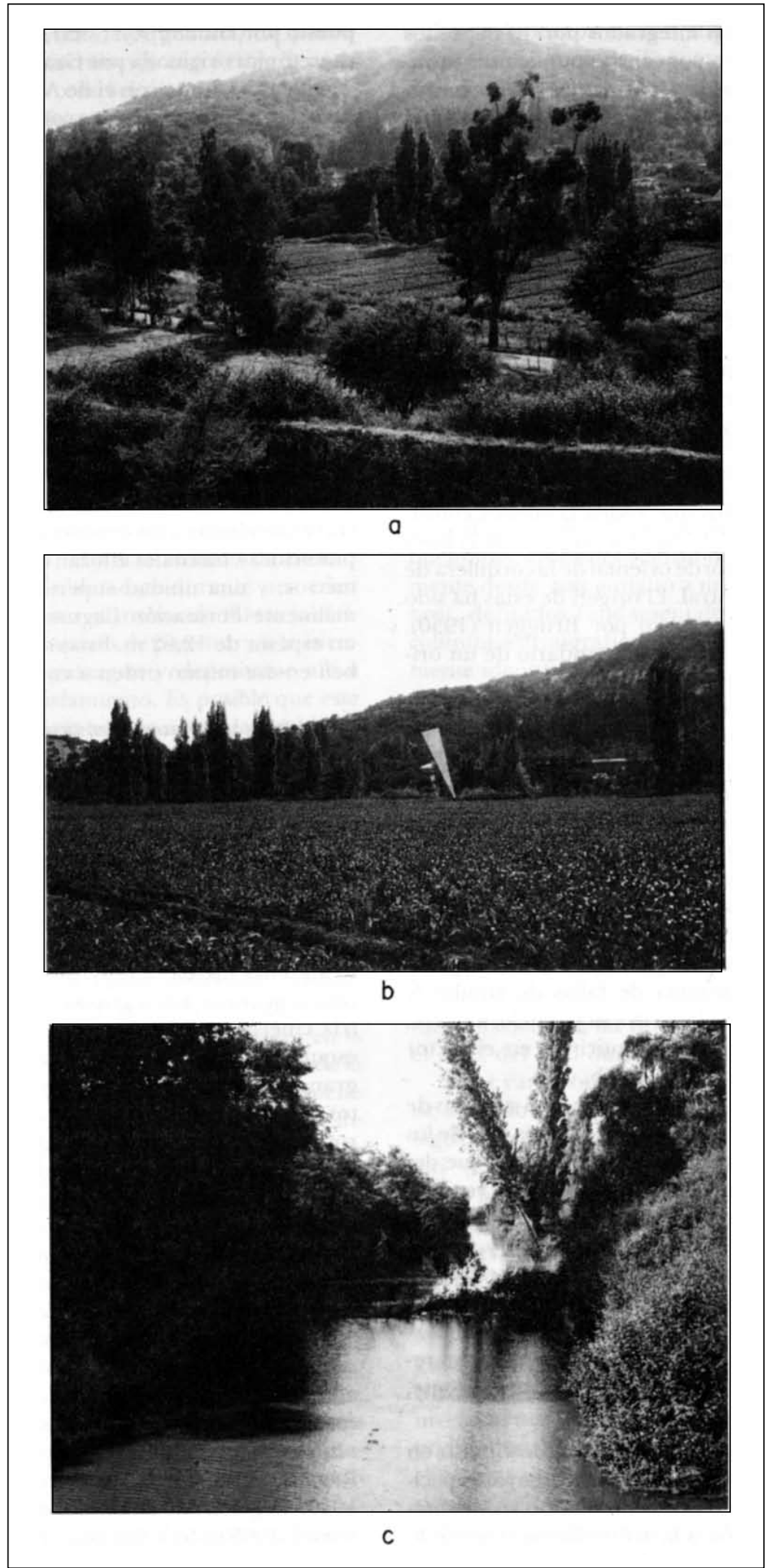

Figura 4. a) Cuenca de Tagua Tagua: Sector de la cuenca de Tagua Tagua; b) Plano de la cuenca de Tagua Tagua. La flecha señala el lugar de la excavación (sitio Tagua Tagua 1); c) Canal artificial junto al sitio, por donde se vacía el drenaje de la cuenca. 
dirección norte $38^{\circ}$ este y dos fallas subparalelas: una de dirección norte $53^{\circ}$ oeste, que corre por el borde norte de la depresión, y otra falla de dirección norte $67^{\circ}$ oeste, que corre por el borde sur. Estas fallas integran dos de los sistemas de fallas descritos anteriormente y son paralelas a los valles tectónicos del valle longitudinal y valles del estero Zamorano y río Cachapoal, respectivamente. El tercer sistema de fallas de rumbo norte $10^{\circ}$ oeste desarrollado en el macizo es paralelo, a su vez, al valle tectónico del río Tinguiririca en el sector Santa Cruz-río Rapel (Varela 1976).

Este paralelismo observado entre los tres sistemas de fallas desarrollados en el macizo de cerros, dos de los cuales serían directamente causantes del bloque deprimido central, con los valles tectónicos vecinos, indicaría que todos estos rasgos del relieve se habrían debido a un mismo tipo de solicitaciones $\mathrm{y}$, consecuentemente, durante un mismo proceso tectónico-orogenético. Este proceso tectónico sería el mismo que dio origen durante el Terciario Superior-Cuaternario Inferior a los rasgos principales del relieve de Chile Central: Fase Geográfica (Vicente 1972).

La laguna de Tagua Tagua se habría constituido en esta cuenca-"rinconada" debido a una mayor capacidad de aluvionamiento y de acumulación sedimentaria externa en relación a la acumulación interna, lo cual habría dado lugar a fenómenos de represamiento en la zona de la boca de la "rinconada". Corresponde -en el sistema de clasificación propuesto por Hutchinson (1957) - a un "lago de cuenca tectónica originada por graben o fosa". La laguna de Tagua Tagua, junto con la de Aculeo, Santa Inés, Mallarauco, Batuco y Polpaico constituirían un "Distrito de Lagos", configurándose un ámbito circunlacustre en tierras bajas, de edad pleistocénica, con buenas perspectivas en términos de eventuales ocupaciones tempranas, humanas y faunísticas.

\section{Estratigrafía y sedimentación de los depósitos cuaternarios de Tagua Tagua}

El espesor total de los rellenos estudiados en el canal artificial que drena la cuenca de Tagua Tagua alcanza los $18 \mathrm{~m}$. En ellos se han reconocido dos unidades estratigráficas cuaternarias: una unidad inferior, correspondiente a los depósitos de cenizas volcánicas pumicíticas, las cuales afloran con un espesor de 5 a $6 \mathrm{~m}$; y una unidad superior denominada informalmente Formación Laguna de Tagua Tagua, con un espesor de $12.62 \mathrm{~m}$. Estas dos unidades se describen a continuación:

a) Depósitos de cenizas volcánicas pumicíticas

Afloran en el fondo del canal principal de drenaje con unos 5 a $6 \mathrm{~m}$ de potencia. La base no está expuesta, el techo corresponde a una discordancia de erosión sobre la cual se ubican los depósitos lacustres superiores correspondientes a la Formación Laguna de Tagua Tagua. Estos materiales corresponden a cenizas de granulometría equivalente a arenas medias a muy finas, las cuales gradan a cenizas gravosas hasta gravas y ripios, con escasa matriz cinerítica. Estas cenizas están compuestas por esquirlas (shards) de vidrio volcánico silíceo (80-90\%), granos de cuarzo, feldespatos y biotita. Los fragmentos mayores de formas subangulares corresponden a rocas volcánicas andesíticas, intrusivas intermedias a ácidas y piedras pómez. Estos depósitos se presentan masivos, con muy escasa selección en tamaño, y ausencia de orientaciones o de estratificación interna. Esta última sólo se insinúa en algunos niveles en forma de estratificación entrecruzada y lentes o bolsones de límites difusos.

Estos depósitos de cenizas se correlacionan de acuerdo a sus propiedades litológicas-estructurales y a su posición estratigráfica con los depósitos cineríticos de características similares que afloran en diferentes puntos de la región Metropolitana y de la VI región (Bruggen 1950; Karzulović 1960; Doyel et al. 1964; Segerstrom et al. 1964, Stiefel 1965a, 1965b; Borde 1966; Santana 1968, 1971). De acuerdo además con la descripción entregada por Polansky (1962) para el "Complejo Piroclástico Pumíceo" que aflora en la zona cordillerana y precordillerana de la provincia de Mendoza (Argentina), se puede plantear también una correlación entre estos depósitos de cenizas y dicho complejo.

El mecanismo de formación de estos depósitos cineríticos, planteado por los diferentes autores, es muy variado, y comprende desde el glaciar al eólico, corriente de barro, lahárico e ignimbrítico. En relación a la edad, la mayoría de los autores les atribuyen tentativamente una edad aproximada al Pleistoceno Medio.

Génesis. Las propiedades que se han observado en los depósitos de cenizas de la laguna de Tagua Tagua permiten clasificarlos como diamictos formados a partir de corrientes densas originadas por procesos 
de remoción en masa de flujo rápido. De acuerdo, asimismo, con la composición de estos depósitos, se puede inferir que estos flujos han sido originados por un volcanismo explosivo intenso de carácter ácido, el cual habría provocado el derretimiento de hielo y nieve cordillerano, posiblemente durante una edad glacial, dando origen a avalanchas de masas laháricas, las cuales fueron capaces de penetrar en la cuenca de la laguna de Tagua Tagua y depositarse allí a pesar de su relativo aislamiento. Es posible que este fenómeno volcánico haya estado asociado también a la producción de depósitos eolocineríticos e ignimbríticos en otras áreas.

En relación a la edad de estos depósitos laháricos de cenizas, los únicos antecedentes de que se dispone en esta cuenca indican que subyacen a los depósitos lacustres, a los cuales se les ha calculado por extrapolación una antigüedad para la base de 57000 años AP, siendo, en consecuencia, la edad de las cenizas anterior a dicha cifra. Un trabajo publicado recientemente por Stern y colaboradores (1984) apoya la equivalencia de los depósitos cineríticos pumicíticos existentes en la zona metropolitana con los de la VI región y los de Argentina, y entrega una datación para el fenómeno volcánico que les habría dado un origen de $450.000 \pm 60000$ años AP Esta datación ubica el fenómeno durante la edad glacial Mindel, según la Geological time table de Van Eysinga (1981).

\section{b) Formación Laguna de Tagua Tagua}

Definición y distribución. Con este nombre se designa al conjunto de sedimentos finos de origen lacustre que constituyen la parte superior del relleno cuaternario de la cuenca de Tagua Tagua. Estos depósitos corresponden a gravillas arenosas y gravas en la base, a las cuales se superponen arcillas, limos y arenas finas que culminan en el techo con limos arcillosos, en gran parte carbonosos y diatomáceos. La base de esta unidad descansa por medio de una discordancia de erosión sobre los depósitos de cenizas, mientras que su límite superior lo constituye la superficie actual del relleno de la cuenca.

Estos depósitos cubren superficialmente toda la cuenca de la laguna de Tagua Tagua; la mejor exposición de ellos la procura, sin embargo, el canal colector principal que surca la cuenca desde su sector central hasta el margen norte (Figura 4c). En los cortes de dicho canal, en especial en su extremo septentrional, quedan expuestos $12.62 \mathrm{~m}$ de esta formación en posición horizontal. Esta exposición en los cortes del canal artificial disminuye continuamente al sur del sector mencionado, para quedar en 1 o $2 \mathrm{~m}$ en el área central de la cuenca.

\section{Columnas estratigráficas de Tagua Tagua}

Con el objeto de describir los depósitos de esta formación se levantaron dos Columnas Estratigráficas: 1 - Excavación y 2 - Represa. De acuerdo al análisis, se decidió subdividir la formación en ocho miembros, los cuales fueron numerados correlativamente desde más antiguo a más nuevo. Estos miembros, definidos fundamentalmente en el sitio de la columna estratigráfica 1 - Excavación, son fácilmente identificables tanto por su carácter litológico como por las pequeñas discordancias de erosión e hiatos que los separan entre sí (Varela 1976a).

\section{Descripción y génesis de la Formación}

Las características de los depósitos de la Formación Laguna de Tagua Tagua, en especial su litología, tipo de contactos entre los diferentes miembros y otros rasgos sedimentológicos, han permitido determinar las condiciones que tuvo el lago de Tagua Tagua en el pasado. Entre estas condiciones, la más importante desde el punto de vista paleogeográfico es la que dice relación con las fluctuaciones que experimentó el nivel del lago durante el Cuaternario Superior.

Estas variaciones de nivel han sido interpretadas de acuerdo a la Teoría de fluctuación glacial de los lagos sin drenaje ubicados en zonas áridas y semiáridas (Deevey Jr. 1960; Flint 1957, 1965; Broecker 1965; Morrison 1965a, 1965b), como respuestas a cambios fundamentales en las condiciones climáticas regionales, las cuales estarían a su vez relacionadas con los cambios climáticos desarrollados en las altas latitudes, representados por los períodos glaciales e interglaciales. Al comparar, en consecuencia, los antiguos niveles del lago de Tagua Tagua, inferidos a través del estudio de los depósitos lacustres, con el nivel que tuvo la laguna en su etapa histórica, se han podido establecer cualitativamente las variaciones climáticas que han afectado la zona, de acuerdo al siguiente esquema: los niveles más altos que el actual indicarían un clima más frío y lluvioso que el existente en la actualidad en la zona, y los niveles más bajos corresponderían a climas más cálidos y secos. Los antecedentes obtenidos al aplicar este principio han sido cotejados, a su vez, con las evidencias climáticas aportadas por el estudio de los restos orgánicos 
contenidos en diferentes niveles de los depósitos lacustres (Casamiquela 1969, 1969-1970, 1976; Redón y Espinoza 1969; Covacevich 1971). Estas evidencias han servido para comprobar el sentido de la variación climática y para cuantificar, en algunos casos, el orden o rango de esta variación.

La sucesión de cambios climáticos determinada según el planteamiento anterior se complementa con los fechados radiocarbónicos de los niveles 1.04 m y 2,35 m (Montané 1968a, 1969) de la columna estratigráfica 1 - Excavación. Estos fechados permiten disponer de una cronología absoluta para el tramo superior de la columna. Por medio de estas mismas dataciones se ha calculado una razón de acumulación de sedimentos para el tramo señalado, la cual corresponde a $20.65 \mathrm{~cm}$ cada mil años. La aplicación de esta razón a los tramos inferiores de la columna ha permitido disponer de un esquema cronológico tentativo o aproximado para el total de la columna de la Formación Laguna de Tagua Tagua. Este esquema se discute de acuerdo a las variaciones litológicas y a la existencia de superficies de discordancia o hiatus interpuestos. En ese sentido también ha servido de control la datación radiocarbónica informada por Heusser (1966a), la cual indica una edad superior a 32000 años AP para la base de un testigo de $10.7 \mathrm{~m}$ cortado en los depósitos lacustres de Tagua Tagua, así como las dataciones informadas en un trabajo más reciente de dicho autor (Heusser 1983). En ese mismo trabajo palinológico se entregan algunas conclusiones climáticas, las cuales son básicamente concordantes con las obtenidas en el trabajo estratigráfico-sedimentológico realizado en la zona (Varela 1976a).

A continuación se entrega, en forma resumida, la descripción y los principales aspectos genéticos de cada Miembro de la Formación Laguna de Tagua Tagua. Estos se presentan ordenados de más antiguo a más nuevo (Varela 1976b).

\section{Descripción y génesis Miembro 1}

Esta unidad se ubica bajo $10.58 \mathrm{~m}$ en la columna estratigráfica 1 - Excavación, siendo desconocida su base allí, y entre los 11.37 y los $12.62 \mathrm{~m}$ en la columna estratigráfica 2 - Represa. El límite superior es transicional al Miembro 2, mientras que el inferior corresponde a una superficie de discordancia de erosión que lo separa de los depósitos de cenizas pumicíticas subyacentes. El Miembro 1 está constituido por gravas arenosas y arenas gravosas en gran parte arcillosas, con poco desarrollo de estratificación y sólo algunos esbozos de estratificación entrecruzada o presencia de bolsones y paleocanales (Figura 5).

Previo a la depositación del Miembro 1 se desarrolló un período más o menos prolongado de erosión en la cuenca, el cual afectó las cenizas inferiores y dio lugar a la discordancia de erosión que constituye la base de la Formación. Sobre esta discordancia se depositó el Miembro 1 constituido por abanicos aluviales-torrenciales y conos de deyección formados en un ambiente subaéreo. Las condiciones climáticas durante el período de erosión previo a la depositación del Miembro 1, se estima que corresponden a un clima cálido y seco con desarrollo regional semiárido; durante la depositación de esta unidad la situación habría cambiado a condiciones climáticas templadas a cálidas y más lluviosas. La edad estimativa del Miembro 1, calculada por extrapolación de la razón de acumulación de sedimentos, correspondería a 57000 años AP para la base y 51000 años AP para el techo. Estas pueden considerarse edades mínimas.

\section{Descripción y génesis del Miembro 2}

Esta unidad está comprendida entre los $7.25 \mathrm{~m}$ y $10.58 \mathrm{~m}$ de profundidad en la columna estratigráfica 1 - Excavación, con un espesor de $3.33 \mathrm{~m}$. Sus límites inferior y superior corresponden a contactos gradacionales con los Miembros 1 y 3 , respectivamente. El Miembro 2 está constituido en ambas columnas estratigráficas por arcillas bastante puras y masivas de colores gris-verdosos, que hacia el techo se hacen más parduscas, en la misma medida en que estas arcillas se hacen más limosas.

Esta unidad se depositó bajo condiciones lacustres, representadas por un lago de gran extensión y profundidad. Estas condiciones habrían sido más marcadas durante la depositación de la parte inferior de la unidad, decreciendo luego hacia la parte superior. Las condiciones climáticas durante la depositación del Miembro 2 corresponderían a un clima frío y lluvioso, el cual habría variado a condiciones menos extremas hacia el techo. Estas inferencias climáticas concuerdan con los antecedentes aportados por Covacevich (1971), quien, de acuerdo a estudios en la población de Tropicorbis presentes en este nivel, postula un clima más frío y lluvioso que el actual, similar al que se desarrolla en la actualidad en la zona de Puerto Montt. Las edades estimativas del Miembro 2, calculadas por extrapolación de la razón 


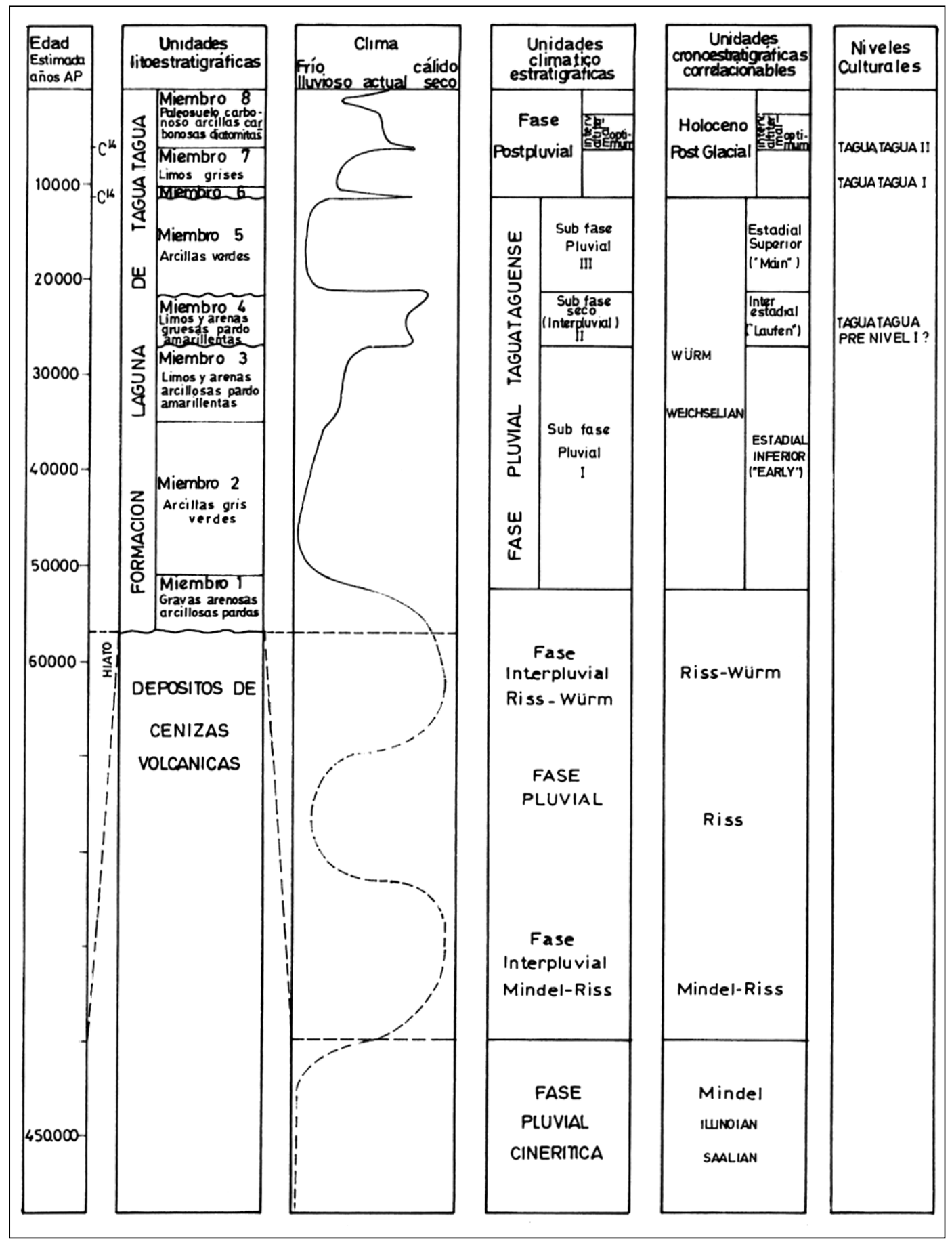

Figura 5. Cuadro litocronológico y climaticoestratigráfico de los depósitos cuaternarios de la cuenca de la laguna de Tagua Tagua. 
de acumulación de sedimentos, corresponden a 51000 años AP para la base y 35000 años AP para el techo. Estas edades, que pueden considerarse mínimas, son concordantes con la edad superior a 32000 años AP informada por Heusser (1966) para una profundidad similar en los rellenos de la cuenca.

\section{Descripción y génesis del Miembro 3}

Este miembro se ubica en la columna estratigráfica 1 - Excavación entre los 5.61 y los $7.25 \mathrm{~m}$ de profundidad, con una potencia de $1.64 \mathrm{~m}$. Su límite inferior corresponde a un contacto gradacional con el Miembro 2, mientras que su límite superior lo constituye una superficie de discordancia de erosión que lo separa del Miembro 4. Esta unidad está compuesta en la columna de la excavación por limos arcillosos de colores grises-amarillentos, los cuales gradan hacia la columna de la represa a arenas muy finas limo-arcillosas de colores pardoamarillentos.

El Miembro 3 se depositó bajo condiciones lacustres someras, representadas por un lago poco profundo, cuya extensión cubría, no obstante, el fondo plano de la cuenca, hasta la base de los cerros que la rodean, desarrollando en la zona comprendida entre la columna de la represa y el pie de los cerros, una delgada lámina de agua. Al término de la depositación del Miembro 3, el lago Tagua Tagua se secó completamente (o se restringió a una zona pequeña central), quedando sus fondos expuestos a la erosión subaérea, y originándose la superficie de discordancia de erosión que constituye su techo. El clima, durante la depositación del Miembro 3, correspondería a un ambiente templado algo frío y moderadamente lluvioso. Los antecedentes planteados por Covacevich (1971), derivados del estudio de los moluscos fósiles presentes en este nivel, indican un clima más frío y lluvioso que el actual, similar al que se desarrolla en la actualidad en la zona de Puerto Montt. Al término de la depositación del Miembro 3 , estas condiciones variaron a un clima cálido y seco con promedios de temperatura superiores al actual y con niveles de precipitaciones más bajos. La edad calculada por extrapolación para el Miembro 3, corresponde a 35000 años AP para la base y 27000 años AP para el techo.

\section{Descripción y génesis del Miembro 4}

Esta unidad se ubica en la columna estratigráfica 1 - Excavación entre las profundidades de $4.49 \mathrm{~m} \mathrm{y}$
$5.61 \mathrm{~m}$, con un espesor de $1.12 \mathrm{~m}$. Sus límites superior e inferior corresponden a planos de discordancia de erosión que lo separan de los Miembros 5 y 3, respectivamente. El Miembro 4 está constituido en la zona de la excavación por limos y limos arcillosos, con una intercalación de gravilla cerca de la base, los cuales gradan lateralmente hacia la zona de la represa a gravillas arenosas y arenas gruesas a finas con clastos, cementadas con óxidos de fierro y manganeso. En la capa basal de la zona de la excavación se ubicó una cornamenta y una porción decúbito derecho de ciervo Antifer sp. (Casamiquela 1969, 1969-70, 1970).

Esta unidad se depositó bajo condiciones lacustres muy someras, representadas por un lago poco profundo, cuya extensión no alcanzó a cubrir el fondo de la cuenca hasta la base de los cerros que la rodean. La línea de costa o ribera del lago se ubicaba, en este momento, en una posición intermedia entre la columna de la excavación y la columna de la represa, correspondiendo el ambiente en esta última zona a condiciones subaéreas. Al término de la depositación del Miembro 4, el lago se secó completamente (o se restringió a un área central muy pequeña), quedando expuestos sus fondos a la erosión subaérea. En este momento se origina la discordancia de erosión que constituye el techo de la unidad. Las condiciones climáticas durante la depositación del Miembro 4 corresponden a un clima cálido y templado y poco lluvioso. Estas condiciones climáticas, así como las relativas al nivel del lago, concuerdan con los antecedentes aportados por Casamiquela (19691970, 1976) sobre la base del estudio de los restos de cérvidos ubicados cerca de la base de este miembro. Estos antecedentes indicarían una temperatura más alta que la actual ("subtropical") durante la depositación de la capa portadora y la probabilidad de que este ciervo haya muerto en el agua, con un nivel no demasiado alto ("ciervo de los pantanos"). Las condiciones climáticas, al término de la depositación del Miembro 4, cambian a un clima cálido más bien seco a árido. La edad estimada para el Miembro 4, de acuerdo a la extrapolación de razones de sedimentación, corresponde a 27000 años AP para la base y 21700 años AP para el techo. Estas pueden ser consideradas edades mínimas.

\section{Descripción y génesis del Miembro 5}

Esta unidad se ubica en la columna estratigráfica 1 - Excavación, entre $2.35 \mathrm{~m}$ y $4.49 \mathrm{~m}$ de profundidad, con un espesor de 2,14 m. Sus límites 
inferior y superior corresponden a discordancias de erosión que lo separan de los Miembros 4 y 6 , respectivamente. El plano inferior se presenta afectado por perforaciones o galerías construidas por un organismo excavador de tipo roedor, batracio, crustáceo u otro, en los limos del Miembro 4 y rellenadas por los depósitos basales del Miembro 5. Esta unidad está constituida tanto en la columna Excavación como en la Represa por arcillas bastante puras, masivas y homogéneas, las cuales constituyen prácticamente un estrato único. En ellos se ubican restos esqueletarios de aves y peces y cerca del techo restos óseos de vertebrados mayores.

Esta unidad se depositó bajo condiciones lacustres representadas por un lago extenso y profundo que cubría todo el sector deprimido de la cuenca, superando en varios $\mathrm{m}$ el nivel que tuvo la laguna de Tagua Tagua en tiempos históricos. Estas condiciones no variaron aparentemente durante toda la depositación de la unidad. Al término de esta depositación, el lago se secó total o parcialmente, quedando expuestos sus fondos a la erosión subaérea, originándose en este momento la discordancia de erosión que constituye su techo. Las condiciones climáticas correspondieron a un clima muy frío y lluvioso, el cual persistió sin cambios importantes durante el lapso de depositación. Estas condiciones concuerdan con la información aportada por Covacevich (1971), quien sugiere que la ausencia de fauna fósil de moluscos en esta unidad podría deberse a "condiciones ecológicas adversas para su desarrollo, tales como una fase glacial o, mejor, un estadial". Al finalizar la depositación del Miembro 5 , las condiciones variaron bruscamente hacia un clima templado a cálido, más bien seco o poco lluvioso, con descenso marcado del nivel del lago y desarrollo de playas lacustres laterales, sobre las cuales se realizaron actividades de caza y faenamiento paleoindio. La edad estimada por extrapolación para la base del Miembro 5 corresponde a 21700 años AP La edad del techo se apoya en los fechados $\mathrm{C}^{14}$ realizados en la base del miembro inmediatamente superior y corresponde a 11400 años AP.

\section{Descripción y génesis del Miembro 6}

Esta unidad está comprendida en la columna estratigráfica 1 - Excavación, entre los 2.07 m y $2.35 \mathrm{~m}$ de profundidad, con un espesor de $0.28 \mathrm{~m}$. Su límite inferior corresponde a un plano de discordancia de erosión que la separa del Miembro 5, mientras que su límite superior corresponde a un contacto gradacional con el Miembro 7. La superficie de discordancia inferior consiste en un plano suavemente ondulado con desarrollo de depresiones o bolsones. Sobre esta superficie se deposita un paleosuelo limo arcilloso-carbonoso de color gris oscuro, casi negro, el cual presenta espesores variables entre 10 y $20 \mathrm{~cm}$, acuñándose totalmente en algunos sectores. En las depresiones se encuentran numerosos restos óseos de vertebrados, entre los cuales se pueden señalar: mastodonte (Cuvieronius humboldtii), caballo (Hippidion sp.), ciervo huemul (Hippocamelus sp.) y zorro culpeo (y/o Canis), así como restos óseos de ranas, coipos, ratones, aves, peces y posibles huesecillos dérmicos de milodontinos (Casamiquela 1969, 19691970, 1976). Asociados a ellos aparecen artefactos consistentes en cuchillos, raspadores, lascas usadas, retocadores de hueso, etc., pertenecientes a una industria de cazadores recolectores paleoindios de fines del Pleistoceno (Montané 1967, 1968). El material correspondiente, posiblemente en parte a turbas y en parte a fogones, fue fechado en $11380 \pm 320$ años AP (Montané 1968a). Este fechado situado en la base del Miembro 6 ha sido corroborado posteriormente con dos nuevas dataciones. Sobre el paleosuelo y constituyendo el techo de la unidad se dispone una capa de diatomita blanca, bastante pura, con abundantes espículas de esponja. Esta diatomita presenta las características de una seudobrecha o brecha diagenética (González-Bonorino y Teruggi 1952) con seudoclastos de 2 a $5 \mathrm{~cm}$.

El paleosuelo basal del Miembro 6 se depositó bajo condiciones temporalmente subaéreas. En este momento el lago de Tagua Tagua se restringía a un sector central de la cuenca, mientras que el área de las columnas correspondía a una zona costera o de playa lacustre de tipo pantanoso o anegadizo, inundada secular o estacionalmente por las aguas del lago. Esta situación aparece corroborada también por la opinión de Casamiquela (1976), basada en el estudio de los restos de vertebrados y por los antecedentes ecológicos derivados del estudio de los moluscos fósiles realizado por Covacevich (1971). Durante la depositación de la diatomita superior el lago experimentó un leve alzamiento de nivel, cubriendo la planicie de la cuenca hasta el pie de los cerros que la rodean. La profundidad de este lago fue, sin embargo, muy pequeña, desarrollando sólo una delgada lámina de agua en la zona de las columnas. Esto aparece corroborado por el carácter netamente epifítico de las diatomeas que componen este depósito (Redón y Espinoza 1969). Las características 
del depósito diatomáceo indican, además: aguas claras, baja temperatura, $\mathrm{pH}$ neutro o levemente alcalino y abundantes nutrientes ( $\mathrm{Si}, \mathrm{N}$ y $\mathrm{P}$ ) en el agua del lago. Las condiciones climáticas durante la formación del paleosuelo inferior corresponden a un clima templado con escasas precipitaciones. Estas condiciones varían durante la depositación de las diatomitas a un clima frío y moderadamente poco lluvioso. Covacevich (1971), de acuerdo al estudio de los moluscos fósiles presentes, determina la vigencia de un clima más frío y húmedo que el actual durante la depositación de los Miembros 6 y 7 de la Formación. Este clima habría sido similar al que existe en la actualidad en la zona de Temuco. La edad del Miembro 6 corresponde a 11400 años AP para la base, de acuerdo a los fechados radiocarbónicos, y a 10250 años AP para el techo, según la interpolación de la razón de acumulación de sedimentos.

\section{Descripción y génesis Miembro 7}

Esta unidad se ubica entre $1.04 \mathrm{~m}$ y $2.07 \mathrm{~m}$ en la columna estratigráfica 1 - Excavación, con un espesor de $1.03 \mathrm{~m}$. Su contacto inferior es gradacional con el Miembro 6, mientras que su contacto superior es concordante con el Miembro 8. El Miembro 7 está constituido en ambas columnas por limos de colores grises a grises-amarillentos, con abundantes restos fósiles de moluscos (Tropicorbis taguatagüensis) (Covacevich 1971). Estos limos son de aspecto masivo y de una gran homogeneidad tanto lateral como vertical. Varían desde limos finos arcillosos en la base a limos medios a gruesos en el techo. Junto con los restos de moluscos se presentan test de diatomeas, espículas de esponjas, carófitas, ostrácodos, escamas de peces, huesos de ranas y aves, semillas y fragmentos carbonosos.

Esta unidad se depositó en un ambiente lacustre representado por un lago bastante extenso y relativamente profundo que cubrió la zona plana de la cuenca. Esta profundidad habría sido máxima durante la depositación del tramo inferior de la unidad, decreciendo luego gradualmente hacia la parte superior. La presencia de oogonios fósiles de carófitas en el sector medio y superior de la unidad, de ser in situ, permitiría estimar la profundidad que tuvo el lago en el sector de la excavación durante ese período. De acuerdo a Hesse y colaboradores (1966) y Martínez y Osorio (1963) esta profundidad podría estimarse comprendida entre 6 y $12 \mathrm{~m}$. Al término de la depositación del Miembro 7 el lago se seca total o parcialmente, quedando sus fondos expuestos a la erosión subaérea en el área estudiada. Las condiciones climáticas durante la sedimentación del tramo inferior del Miembro 7, corresponderían a un clima templado a frío y lluvioso variando a condiciones menos frías y lluviosas hacia la parte superior de la unidad y cambiando luego bruscamente a condiciones climáticas cálidas a templadas, más bien secas o muy poco lluviosas al término de la depositación de esta unidad. Covacevich (1971) postula el desarrollo de condiciones más frías y húmedas que las actuales durante la depositación de este miembro; estas condiciones climáticas serían similares a las existentes en la actualidad en la zona de Temuco. La edad estimada por interpolación, para la base del Miembro 7, es de 10250 años AP, la edad del techo se basa en los fechados $\mathrm{C}^{14}$ realizados en la base de la unidad superior, y corresponde a 6150 años AP (Montané 1969).

\section{Descripción y génesis Miembro 8}

Esta unidad está comprendida en la columna estratigráfica 1 - Excavación, entre 0 y $1.04 \mathrm{~m}$, con una potencia de $1.04 \mathrm{~m}$. Su contacto basal es concordante con el Miembro 7, mientras que su límite superior lo constituye la superficie actual del terreno. El Miembro 8 se caracteriza litológicamente por una secuencia bastante heterogénea y variable lateralmente de depósitos de distintos tipos. Estos se constituyen en la base por un paleosuelo arcilloso-carbonoso con restos de moluscos y de vertebrados menores (roedores, aves, peces, batracios). En este paleosuelo se ubican además restos de ocupaciones arcaicas, con puntas de proyectiles, piedras horadadas, raspadores, cuchillos líticos, manos de moler y artefactos de hueso en una matriz carbonosa, datados en el VI milenio AP (Montané 1969; Durán 1980). Sobre este paleosuelo se disponen arcillas carbonosas-diatomáceas, y sobre éstas, constituyendo la parte superior de la unidad, diatomitas, arcillosas y diatomitas puras. En estos depósitos se intercalan además arenas gruesas y gravas en la zona de la represa.

El ambiente de depositación del paleosuelo basal corresponde a una zona de playa lacustre de tipo pantanoso-anegadizo, cubierta estacional o secularmente por sus aguas, ubicada en el borde inmediato al lago. El lago de Tagua Tagua, en consecuencia, se restringía a un sector central y pequeño de la cuenca. Las condiciones climáticas en este momento deben haber sido templadas a cálidas con escasas precipitaciones. La depositación de las arcillas 
carbonosas-diatomáceas más altas registran un alzamiento del nivel del lago, el cual cubre toda la planicie de la cuenca, desarrollando profundidades medianas. Las condiciones climáticas en este momento se pueden definir como de clima templado y moderadamente lluvioso, muy similar al actual de la zona. Las diatomitas superiores registran un descenso del nivel del lago, con desarrollo de una delgada lámina de agua en la zona de la columna de la excavación y exposición subaérea en la zona de la columna de la represa, bajo condiciones climáticas frías a templadas y moderadamente a poco lluviosas. El lago experimenta posteriormente una leve alza de nivel y extensión, adquiriendo las características que tuvo durante la etapa histórica, en la misma medida que las condiciones climáticas cambian a las condiciones templadas y moderadamente lluviosas actuales. La edad de la base del Miembro 8 se apoya en la datación radiocarbónica efectuada en el paleosuelo, la cual corresponde a 6150 años AP La edad del techo corresponde a la actual, o más exactamente a la fecha en que la laguna de Tagua Tagua fue desecada artificialmente con el objeto de utilizar sus terrenos para la agricultura (100 años AP).

\section{Historia geológica y estratigrafía del cuaternario superior de Tagua Tagua}

En esta sección se entrega una síntesis de los rasgos más relevantes de la secuencia de eventos registrada. Esta síntesis se presenta gráficamente en las tres primeras columnas del cuadro litocronológico y climaticoestratigráfico de los depósitos cuaternarios de la cuenca de la laguna de Tagua Tagua.

En las dos primeras columnas de la Figura 5 se indican las unidades litoestratigráficas reconocidas en la cuenca y las edades que se han estimado para ellas. Esta cronología estimativa se basa, según ha sido explicado, en la extrapolación de la razón de acumulación de sedimentos lacustres determinada por fechados $\mathrm{C}^{14}$ en los miembros superiores de la Formación Laguna de Tagua Tagua. De esta forma se ha determinado una cronología continua para dicha formación y sus miembros, la cual va desde 57000 años AP hasta la fecha actual.

En relación a la cronología de los eventos ocurridos en la cuenca antes de la depositación de la Formación Laguna de Tagua Tagua, sólo se dispone de la datación informada por Stern y colaboradores (1984), efectuada en cenizas pumicíticas correlacionables con las que forman la base del relleno de la cuenca. Estos eventos corresponden, por una parte, a la depositación de las cenizas pumicíticas de probable origen lahárico en la base de la secuencia y, por otra parte, a la etapa de erosión e hiato desarrollada posteriormente sobre estos mismos depósitos cineríticos.

De acuerdo a la datación de $450.000 \pm 60000$ citada anteriormente (Stern et al. 1984), la depositación de las cenizas pumicíticas laháricas basales habría tenido lugar durante la edad glacial Mindel (Van Eysinga 1981), mientras que el período de erosión e hiato posterior, representaría el transcurso de las edades Glacial Riss e Interglaciales Mindel-Riss y Riss-Würm.

En la tercera columna de la Figura 5 se indican gráficamente, por medio de una curva, las condiciones climáticas que habrían prevalecido durante la depositación de las diferentes unidades litoestratigráficas, con sus correspondientes edades cronológicas. Estas condiciones climáticas, según se explicó anteriormente, han sido determinadas a base de las variaciones del nivel del lago de Tagua Tagua en el pasado, interpretadas de acuerdo a la teoría pluvial y complementadas con las evidencias aportadas por los organismos fósiles y rasgos sedimentológicos específicos de los depósitos estudiados. La curva que representa estas variaciones climáticas se desplaza entre condiciones más frías-lluviosas y más calidas-secas, respectivamente, que las que prevalecen actualmente en la zona. El grado de desplazamiento e inflexiones de esta curva climática tiene un valor sólo cualitativo (no cuantitativo) de comparación entre los diferentes niveles de la columna. En esta curva se establece, asimismo, una diferencia entre un sector superior, dibujado con trazo lleno, el cual representa una secuencia continua de eventos climáticos bien ubicados en el tiempo, correspondiente a los depósitos lacustres, y un sector inferior, dibujado con trazo segmentado, el cual corresponde al período de depositación de las cenizas volcánicas y al período de erosión desarrollado posteriormente. En este sector segmentado de la curva las condiciones climáticas inferidas a partir de un registro sedimentario de tipo discontinuo, tendrían un carácter más bien interpretativo.

La curva climática, junto con los rasgos estratigráficos y paleoecológicos determinados en los depósitos de la cuenca de la laguna de Tagua Tagua, permiten establecer la existencia, en el pasado, de períodos de tiempo en los cuales han prevalecido alternadamente 
condiciones climáticas frías-lluviosas y calidassecas. Estos períodos, de acuerdo a la teoría pluvial, corresponderían a fases pluviales e interpluviales, respectivamente, las cuales serían equivalentes a las fases o edades glaciales e interglaciales desarrolladas en las altas latitudes. Sobre esta base se ha establecido una subdivisión de la historia geológica cuaternaria de la laguna de Tagua Tagua en unidades climático estratigráficas, las cuales se correlacionan con las unidades cronoestratigráficas estándares mundiales. Esta subdivisión y sus correlaciones se plantean gráficamente en la cuarta y quinta columna del cuadro correspondiente a la Figura 5.

La unidad más antigua corresponde a la fase pluvial cinerítica, representada por los depósitos laháricos basales de cenizas volcánicas. Esta fase representaría condiciones climáticas frías y lluviosas para la zona. Esta fase pluvial cinerítica se correlaciona con la edad glacial Mindel, asignándosele una edad de 450.000 años AP.

Las unidades que se desarrollan a continuación corresponden a las fases pluvial e interpluviales, representadas por los procesos de erosión e hiato en la cuenca. Estas fases estarían caracterizadas por el desarrollo de condiciones climáticas cálidas y secas con una fase fría lluviosa intercalada en la zona, estableciéndose su correlación con las edades interglaciales Riss-Würm y glacial Riss, respectivamente. Sus límites cronológicos inferior y superior corresponden a 450.000 años AP y 52500 años AP, respectivamente.

A continuación se desarrolla una fase pluvial con predominio de condiciones climáticas de tipo frío y lluvioso en la zona. Junto con el inicio de esta fase se constituye el lago de Tagua Tagua en la cuenca, por lo cual esta fase ha sido denominada Fase Pluvial Taguatagüense. Sus límites cronológicos corresponden a 52500 años AP y 11500 años AP. Esta fase se correlacionándose con la edad glacial Würm.

En la Fase Pluvial Taguatagüense se reconocen tres oscilaciones climáticas menores o subfases. Estas corresponden a: Subfase Pluvial I (inferior), caracterizada por condiciones climáticas frías-lluviosas con límites cronológicos inferior y superior de 52500 años AP y 27500 años AP, respectivamente; Subfase Seca II (media), caracterizada por condiciones climáticas cálidas y secas, con límites cronológicos de 27500 años AP y 21500 años AP, y Subfase Pluvial III (superior), desarrollada bajo condiciones climáticas frías y lluviosas, entre los 21500 años AP y los 11500 años AP En relación a la Subfase Seca II, cabe hacer notar que a pesar de su carácter intrapluvial, las condiciones climáticas que prevalecieron durante ese período habrían correspondido, al parecer, a un clima más cálido y seco que el que rige actualmente en la zona. Estas subfases se correlacionan con las subdivisiones de la edad glacial Würm planteada por Penck y Bruckner (1909, en Flint 1957). De acuerdo a ello, la Subfase Pluvial I correspondería al Estadial Inferior o Early Würm; la Subfase Seca II, al interestadial Laufen (Penck y Bruckner en Flint 1957), y la Fase Pluvial III, al Estadial Superior o Main Würm.

La última unidad climaticoestratigráfica definida corresponde a la fase postpluvial caracterizada por condiciones climáticas variadas, que, en términos generales, pueden ser definidas, no obstante, como más cálidas y menos lluviosas que la Fase Pluvial Taguatagüense. Esta unidad, de límites correspondientes a 11500 años AP y la fecha actual, se correlaciona con la edad postglacial u Holoceno. Cabe señalar que el límite inferior de esta fase, que correspondería al límite local Pleistoceno-Holoceno, cumple en su ubicación con los requerimientos básicos planteados por Morrison (1969) para dicho límite.

La Fase Postpluvial ha sido subdividida en subfases, de acuerdo al esquema de subdivisión del postglacial planteado inicialmente por Blytt y Sernader y modificado posteriormente por diferentes autores (Zeuner 1956). De acuerdo a ello se reconocen las siguientes subfases correlacionables a subedades y/o subpisos: Alleröd, de clima cálido y seco (11500-10600 años AP); Younger Dryas, de clima más bien frío y lluvioso (10600-8500 años AP); Preboreal, de clima frío a templado y seco (6500-5500 años AP); Atlántico y Subboreal, de clima templado y moderadamente a poco lluvioso (5500-2500 años AP), y Subatlántico, de clima más bien frío y algo lluvioso (2500 años AP-0). En esta subdivisión se ha ubicado el límite Pleistoceno-Holoceno en la base del Alleröd, incorporándose tanto esta unidad como el Younger Dryas al Holoceno. Esta decisión es concordante con la sugerencia planteada por Olausson (1969). Dentro de esta Fase Postpluvial se determina, asimismo, un Intervalo Altitermal, el cual comprende las subfases Boreal, Atlántico y Subboreal, y dentro de éste, a su vez, un optimum climaticum, que equivale a la Subfase Boreal (Figura 6). 


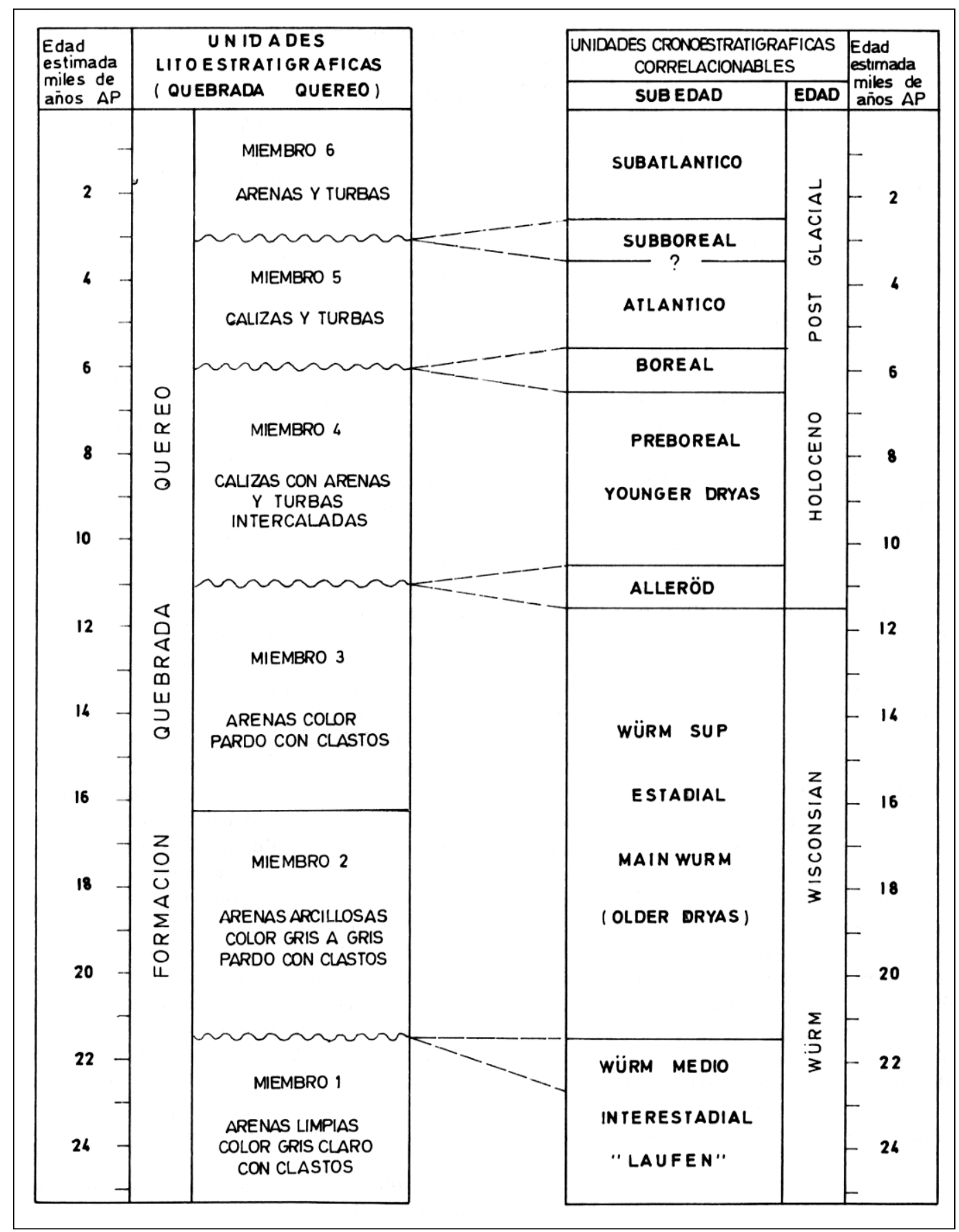

Lámina 6. Correlación estratigráfica para quebrada Quereo.

Es interesante efectuar una comparación entre la secuencia de Tagua Tagua y aquellas de la región de Llanquihue-Aysén, definidas por Heusser (1960, 1961, 1966a, 1966b). Estas secuencias representan registros continuos bastante detallados del Würm
Superior o Late Glacial y el Holoceno. Esta comparación se presenta también gráficamente en la Figura 7, igualándose para este efecto las escalas cronológicas de las secuencias. En ellas se observa concordancia en el Older Dryas, Alleröd, parte inferior 


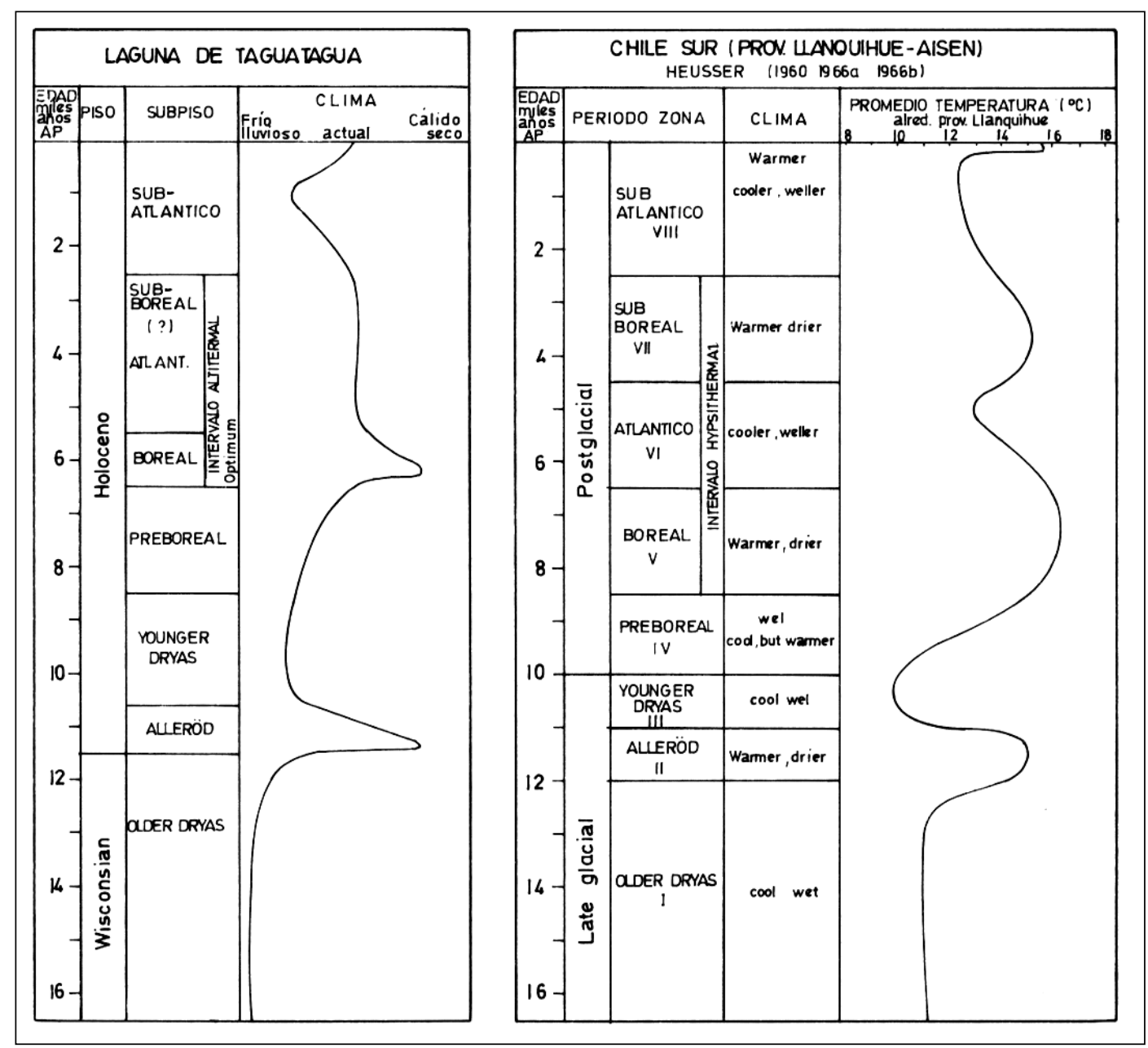

Figura 7. Cuadro comparativo entre la secuencia de eventos del Pleistoceno Superior-Holoceno de la laguna de Tagua Tagua y las secuencias propuestas por Heusser $(1960,1961,1966 a, 1966 b)$ para la región meridional de Chile.

del Younger Dryas y el Subatlántico mientras que se advierte una falta de concordancia en el Preboreal, Boreal, Atlántico y Subboreal.

\section{Antecedentes geográficos, geológicos y geomorfológicos de quebrada Quereo}

La zona estudiada se sitúa al pie del barranco de la cordillera de la Costa integrado por planicies litorales, de alturas comprendidas entre 25 y $180 \mathrm{~m} . \mathrm{snm}$, sobre las cuales descuellan algunos montículos o paleoislotes. El sector está surcado por un solo curso intermitente de agua (en la actualidad seco), correspondiente al estero de la quebrada Quereo. Esta nace por medio de dos ramas en el sector del barranco de la cordilllera de la Costa, confluyendo luego en una quebrada única, a unos $300 \mathrm{~m}$ de su desembocadura en el océano Pacífico (ver Figura 3).
Desde el punto de vista climático, esta zona es semiárida, y está comprendida dentro del sector costero (La Serena-Zapallar), con un "clima de estepa con nubosidad abundante (B Sn)" de acuerdo a la aplicación del sistema de clasificación de Köepen (Fuenzalida P. 1965). Este sector se caracteriza por presentar niveles intermedios a bajos de precipitaciones, con desarrollo de humedad relativa y nubosidad muy alta, debido a la influencia directa del mar.

Las características climáticas de la zona, en especial la alta humedad relativa con desarrollo de frecuentes neblinas rasantes, son condicionantes fundamentales para el tipo de vegetación del sector. De acuerdo a Fuenzalida V. (1965), este sector se incluye en la zona fitogeográfica mesomórfica; más específicamente en la zona de formación de Estepa costera de arbustos y hierbas mesófitas, la cual en algunos sectores de 
la cordillera de la Costa, favorecida por continuas neblinas mojadoras, da lugar a bosques o formaciones arborescentes del tipo de Fray Jorge, Talinay, Silla del Gobernador, etc. Estas condiciones climáticas, sumadas, en este caso, a una abundante provisión de aguas subterráneas, dan origen al bosque relictual ubicado en quebrada Quereo, inmediatamente al oriente de la zona de confluencia y a unos $400 \mathrm{~m}$ de su desembocadura en el mar (Varela 1980).

Las unidades estratificadas que constituyen rocas fundamentales en la zona estudiada corresponden a la Formación Los Vilos, la cual aflora en el sector septentrional constituida por rocas metamórficas (Muñoz-Cristi 1972), de presunta edad paleozoica (carbonífera) (Cecioni y Westermann 1968). Esta unidad está recubierta discordantemente por la Formación El Quereo de edad Triásico Medio (Anisiano) (Cecioni y Westermann 1968), aflorando en el sector medio del área estudiada en una secuencia monoclinal de rumbo este-oeste y manteo $20-30^{\circ} \mathrm{S}$. Sobre la Formación Quereo y constituyendo el sector meridional del área estudiada, se dispone concordantemente la Formación Pichidangui, compuesta principalmente por rocas volcánicas de edad supuesta Triásico Superior-Jurásico Inferior. En el sector ubicado al norte del pueblo de Los Vilos (zona de quebrada El Boldo), las unidades estratificadas correspondientes a Formación Los Vilos y Formación El Quereo están instruidas por un batolítico de granito rosado, el cual se extiende más allá del límite septentrional del área estudiada.

En el área se reconoce un sistema de fallas de rumbo noroeste, el cual es cortado por un segundo sistema de dirección noreste. Un par de fallas pertenecientes al sistema noreste, interceptadas por una falla del sistema noroeste, dan origen, en el sector ubicado al oriente del sitio Quereo 1, a una zona deprimida tectónicamente, denominada Graben Central (ver Figura 3). Esta Graben Central está ocupada parcialmente por depósitos cuaternarios, los cuales se extienden hacia el oeste a través de un estrecho corredor tectónico, representado por el curso inferior de quebrada Quereo. En estos rellenos se ubican los restos arqueológicos y de vertebrados fósiles, que son el objetivo principal del estudio interdisciplinario.

Las unidades geomorfológicas principales que constituyen el área corresponden a: Terraza Marina Alta, desarrollada en el sector oriental del área estudiada cubriendo hasta la base del barranco de la cordillera de la Costa (ver Figura 3). Esta terraza presenta alturas promedios de 120-140 m.snm, con montículos que descuellan sobre ella y que corresponden a antiguos islotes; una Terraza Marina Intermedia, desarrollada en todo el sector centro-occidental con alturas promedios de 25 a 40 m.snm, y también con algunos montículos sobresalientes o antiguos islotes de unos 40 a 50 m.snm; se reconocen restos de una Terraza Marina Baja de unos 6 a 7 m.snm, situados en el margen izquierdo de la desembocadura de quebrada Quereo, al pie del acantilado marino que limita la Terraza Marina Intermedia por el oeste (ver Figura 8). Estos niveles de terrazas marinas serían equivalentes con los niveles descritos por Paskoff (1970) y referidos a los eventos denominados Serenense I (Cuaternario Antiguo), Herradurense I (Cuaternario Medio) y Cachagüense-Veguense (Cuaternario Reciente a Holoceno), respectivamente (Paskoff 1970).

La unidad identificada como Graben Central se localiza entre la Terraza Marina Alta y la Terraza Marina Intermedia, con rellenos cuaternarios (ver Figura 8). La superficie de los rellenos de esta fosa tectónica da origen a una zona bastante plana, algo deprimida en relación a la Terraza Marina Intermedia con alturas promedios de 20 a 25 m.snm. Estos mismos depósitos se extienden con una ligera inclinación, acuñándose en general hacia el oeste, a través del estrecho corredor correspondiente al curso inferior de quebrada Quereo.

Sobre la Terraza Marina Alta y en menor grado sobre la Terraza Marina Intermedia existen depósitos eólicos o antiguos campos de dunas estabilizados, los cuales están siendo removilizados en la actualidad por procesos eólicos, dando origen a zonas de deflación del tipo yardangs asociados a depositaciones en forma de lenguas de arena o lóbulos de dirección noreste. Estos depósitos eólicos actuales se generalizan en la parte baja al recibir nuevos aportes de arenas provenientes del sector costero, dando lugar al amplio campo de dunas del sector interno noroeste de la ensenada El Negro (Figura 9).

\section{Estratigrafía de los depósitos cuaternarios de Quereo}

En los rellenos cuaternarios del Graben Central y curso inferior de quebrada Quereo se han descrito cuatro columnas estratigráficas. De estas columnas, las correspondientes a Q1, Q2 y Q3, respectivamente, se ubican en el sitio mismo de las excavaciones arqueológico-vertebradológicas 







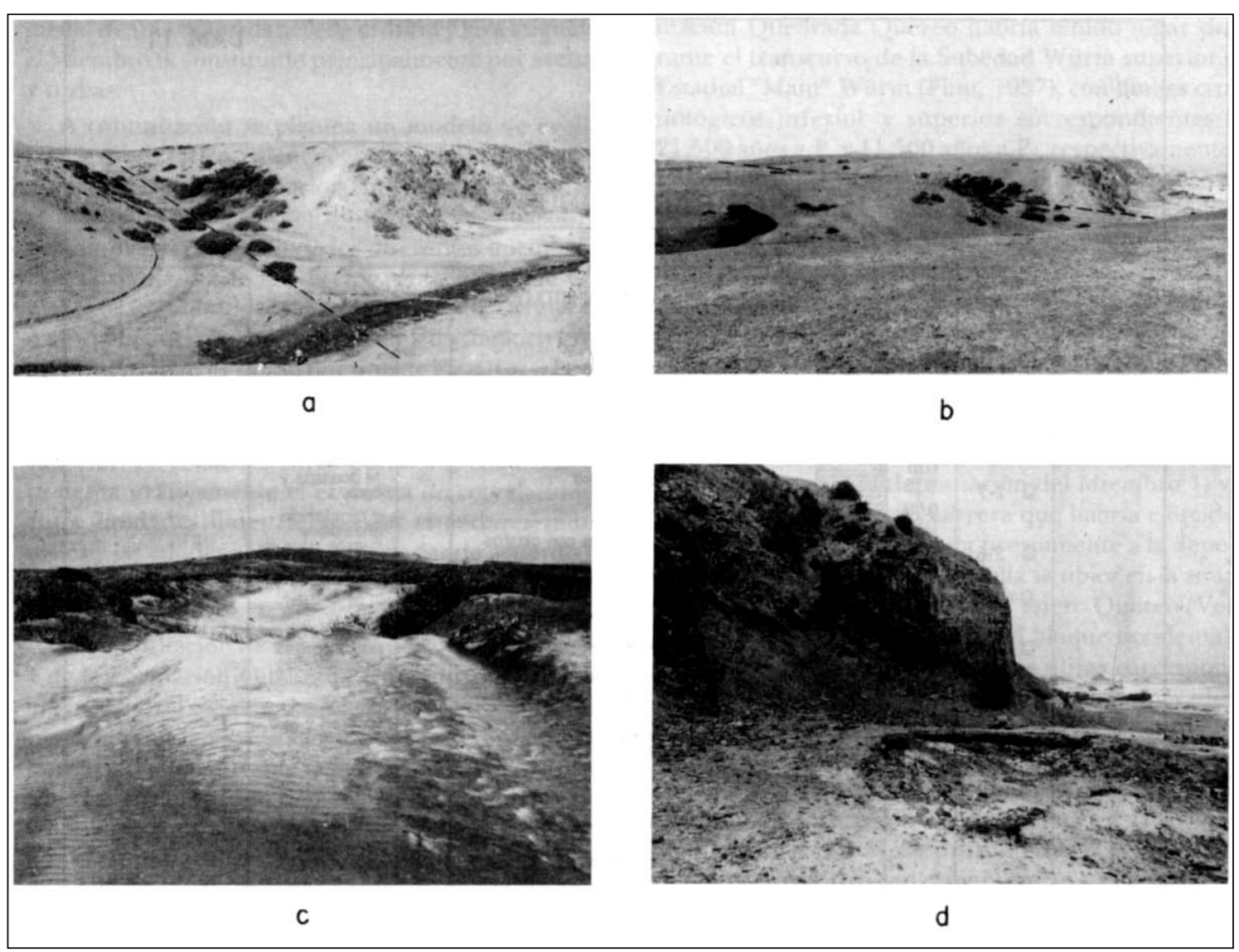

Figura 9. Quebrada Quereo. a) Vista de la barrera rocosa interpuesta en la zona de desembocadura de quebrada Quereo, debido a la acción de las fallas (línea segmentada) de rumbo norte $15^{\circ}$ oeste, que corre por una pequeña quebrada; b) Vista del bloque costero solevantado por la falla norte $15^{\circ}$ oeste (línea segmentada), la cual desplaza la superficie de la Terraza Marina Intermedia y forma una barrera rocosa dura en la zona de desembocadura de quebrada Quereo; c) Sector de removilización de dunas antiguas estabilizadas; atrás, corredor de erosión o deflación eólica alargado en el sentido de los vientos predominantes. Primer plano, lengua de arena eólica desplazada del mismo corredor. En la base del corredor se ubicaron restos de megafauna (megaterio y caballo); d) Restos de la Terraza Marina Baja al pie del acantilado Marino Muerto.

(ver Figura 3 y Figura 10); mientras que la cuarta columna, denominada $\mathrm{Q} 4$, fue levantada en un pozo de exploración de $10 \mathrm{~m}$ de profundidad, situado a unos $200 \mathrm{~m}$ aguas arriba del sitio de la excavación (ver Figura 3 y Figura 10).

La columna estratigráfica Q2 (Figura 11) se puede considerar como representativa de los depósitos del sitio de la excavación. Entre Q2 y la columna Q4 se han establecido, a su vez, algunos niveles de correlación. En la lámina mencionada, junto a la información litológica, se incluyen las unidades litoestratigráficas, las evidencias faunísticas y los diferentes niveles culturales reconocidos con los fechados $\mathrm{C}^{14}$.
La unidad litoestratigráfica definida con carácter informal en los depósitos cuaternarios ha sido denominada Formación Quebrada Quereo. Esta formación de edad Pleistoceno Superior-Holoceno se extiende en capas horizontales a subhorizontales al oriente de la desembocadura del estero Quereo, constituyendo la parte superior de los rellenos del Graben Central. La base de esta unidad no ha sido observada; su espesor máximo, aflorante en los cortes laterales de la quebrada Quereo, alcanza 15 a $20 \mathrm{~m}$ en la parte oriental, los cuales se reducen a 4.5 m en el sector de la columna Q2. Esta formación está constituida en este último sector por arenas con rodados, bloques o cascajos angulosos en la parte inferior, las cuales pasan en la parte superior a turbas, calizas y arenas. 


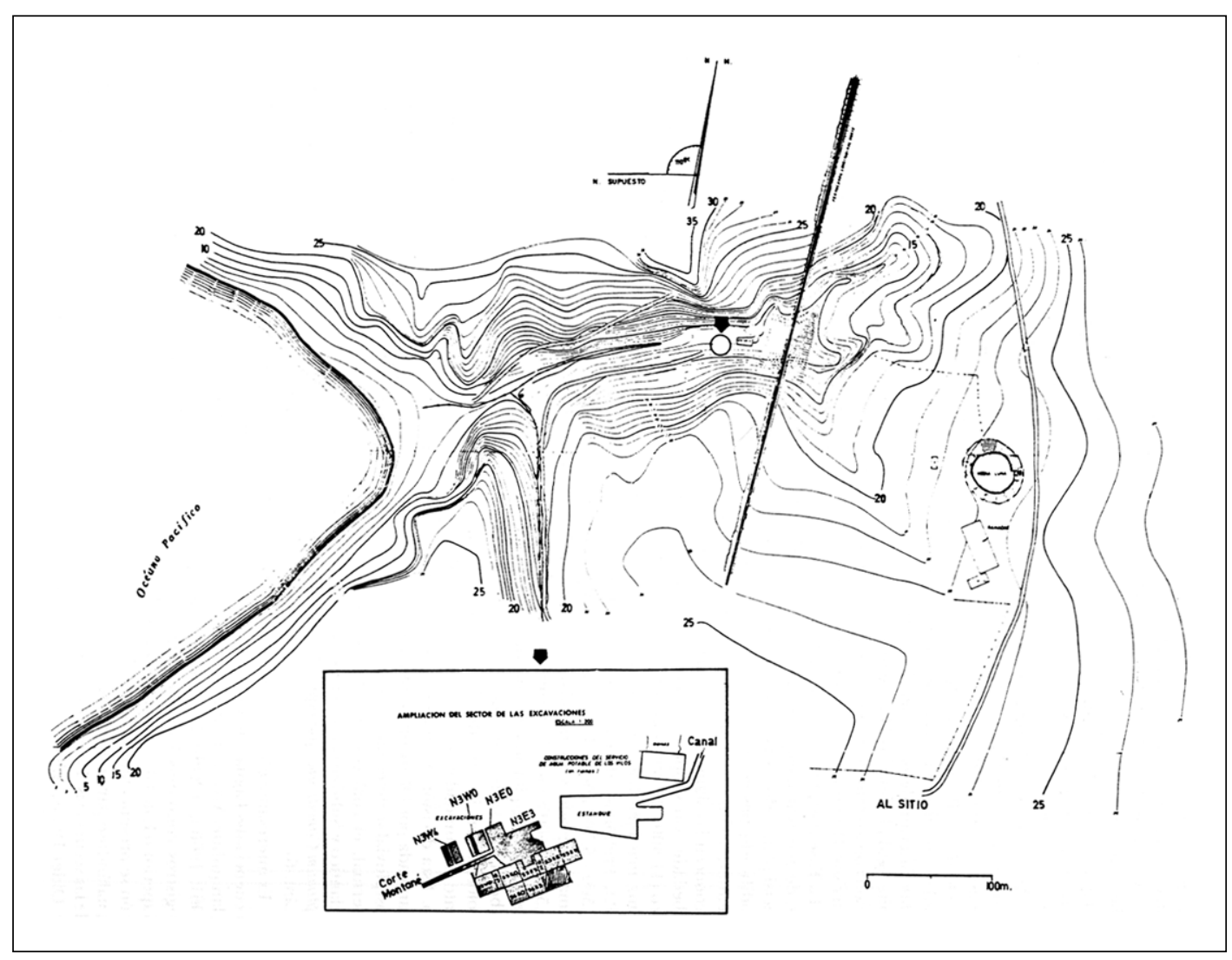

Figura 10. Sitio Quereo 1

En la Formación Quebrada Quereo se han identificado, a su vez, seis miembros, los cuales se denominan por numeración correlativa de más antiguo a más nuevo. Estos miembros son fácilmente reconocibles tanto por sus características litológicas como por las superficies de discordancias de erosión, en algunos casos angulares leves, que los separan. La descripción de estos miembros es la siguiente, de más antiguo a más nuevo: Miembro 1, de límite inferior no observado, está constituido por arenas grises claras, limpias, con algunos clastos redondeados, abundantes restos de moluscos (dulce-acuícolas y marinos) y huesos de vertebrados en su nivel superior (mastodonte, milodón, caballo, paleolama, ciervo Antifer, etc.), con marcas algunos de ellos y eventuales evidencias de caza y faenamiento (Figura 11); a este miembro se superpone discordantemente el Miembro 2, constituido por arenas arcillosas de color gris oscuro a gris-pardo; luego se superpone el Miembro 3, separado del inferior por medio de un contacto gradacional. Este Miembro 3 está constituido por arenas pardas con bloques y cascajos angulosos en su parte superior, así como restos óseos de vertebrados (mastodonte, milodón, caballo, ciervo Antifer, etc.), artefactos y actividad humana de caza y faenamiento (ver Figura 11); hacia arriba se dispone el Miembro 4, sobreyaciendo al anterior por medio de una discordancia de erosión y leve angular. Este Miembro 4 está constituido por calizas blancas con algunas intercalaciones de turbas y arenas. Una nueva discordancia de erosión, esta vez con una angularidad más fuerte, separa al Miembro 4 del 5. Este último está compuesto por calizas turbosas, con algunos niveles de turbas puras intercalados; sobre el Miembro 5 e integrando la parte superior de la secuencia, se dispone por medio de una discordancia de erosión y leve angular, el Miembro 6, constituido principalmente por arenas y turbas.

A continuación se plantea un modelo de evolución estratigráfico-paleogeográfico de la zona, durante el Pleistoceno Superior-Holoceno. Este modelo se basa en la información de tipo sedimentológico y paleontológico extraído de los diferentes miembros, más el resultado de los diferentes fechados de $\mathrm{C}^{14}$ 


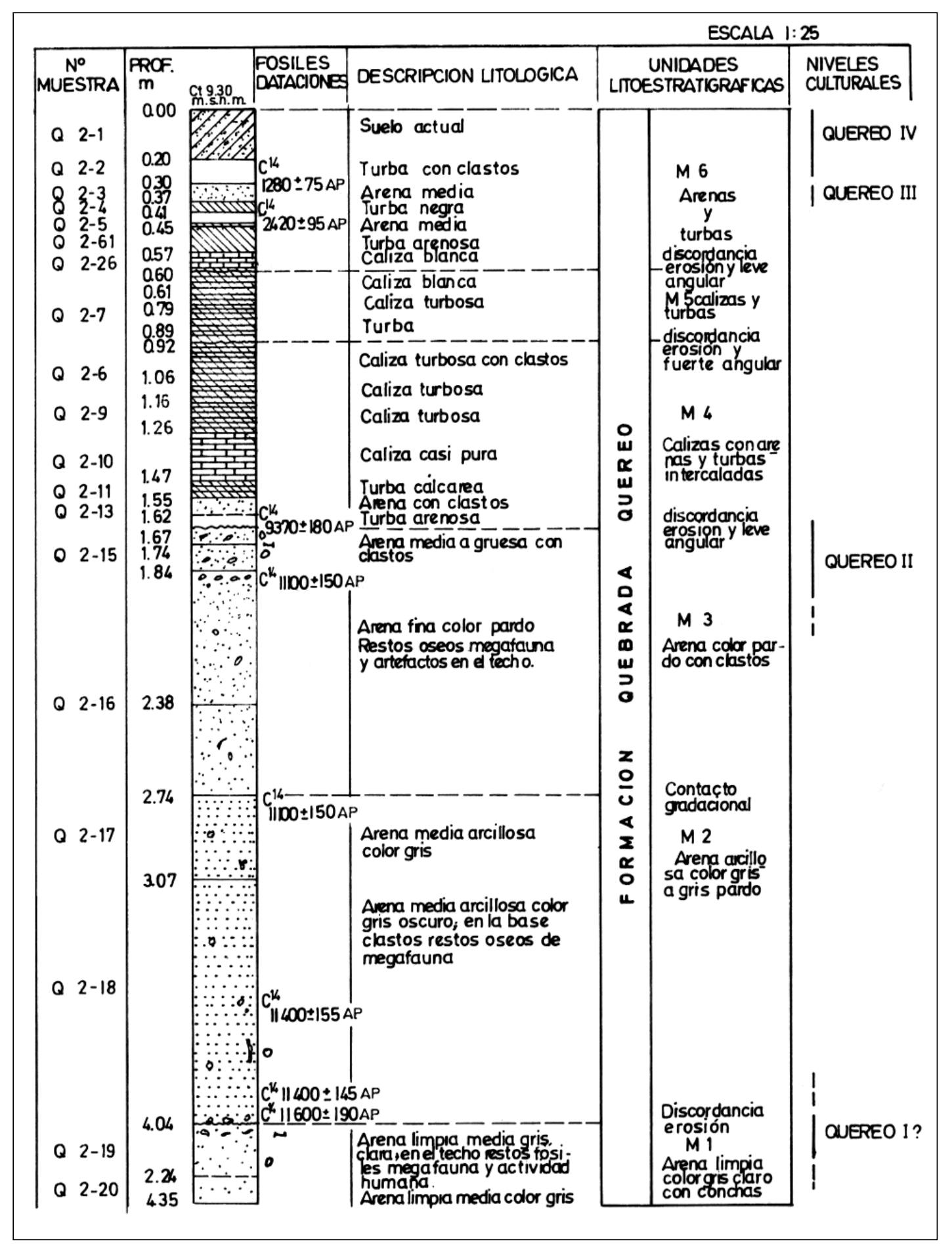

Figura 11. Columna estratigráfica Q2 de quebrada Quereo. 
que se han ejecutado. Este modelo ha sido correlacionado provisoriamente con el cuadro climático cronoestratigráfico definido por uno de los autores en la zona de la laguna de Tagua Tagua, provincia de O’Higgins (Varela 1976a, 1976b). Este último ha sido correlacionado a su vez con el sistema de clasificación cronoestratigráfico estándar mundial del Cuaternario Superior. En la Figura 12 se presenta gráficamente el esquema de correlaciones entre unidades litoestratigráficas estándares mundiales y las edades absolutas estimadas de acuerdo al estudio realizado en laguna de Tagua Tagua (Varela 1976a, 1976b).

La depositación de la parte superior del Miembro 1 de la Formación Quebrada Quereo habría tenido lugar, según el esquema señalado anteriormente, durante el transcurso de la edad glacial Würm, más específicamente durante la Subedad Würm Medio o Interestadial Laufén (Flint 1957), cuyos límites cronológicos inferior y superior corresponderían, según el estudio realizado en Tagua Tagua, a 27500 AP y 21500 años AP, respectivamente. Las condiciones de sedimentación del Miembro 1 en el sitio de la excavación estuvieron determinadas por el nivel que presentaba el mar en ese momento, unos 6 a $7 \mathrm{~m}$ como mínimo sobre el nivel actual. Esta situación provocó la penetración del mar en forma de "caletón" a través del curso inferior de la quebrada hasta el sitio mismo de la excavación, desarrollándose en este último punto un ambiente mixto de playa y desembocadura a su vez en el antiguo estero Quereo. Las condiciones climáticas en este momento habrían variado desde similares hasta más cálidas y secas que las que imperan en la actualidad en la zona. Estas condiciones fueron, al parecer, más marcadas al término de la depositación del Miembro 1, desarrollándose durante ese período un proceso de desecamiento del sector y originándose la superficie de discordancia de erosión que constituye el techo del Miembro 1. Estas condiciones climáticas inferidas a partir de los antecedentes estratigráficos, sedimentológicos y micropaleontológicos reconocidos en esta unidad se apoyan además en la evidencia aportada por el hallazgo en este nivel de una cornamenta y restos óseos del ciervo del género Antifer sp., cuyo hábitat correspondió muy probablemente a un clima cálido (Casamiquela 1969, 1976).

La depositación de los Miembros 2 y 3 de la Formación Quebrada Quereo habría tenido lugar durante el transcurso de la Subedad Würm superior o Estadial Main Würm (Flint 1957), con límites cronológicos inferior y superior correspondientes a 21500 años AP y 11500 años AP, respectivamente. Las condiciones de depositación del Miembro 2 en el curso inferior de quebrada Quereo correspondieron a un ambiente lacustre representado por un depósito de agua relativamente profundo, que ocupaba todo el fondo del curso inferior de la quebrada, limitado en forma de cañón por sus laderas abruptas. Este ambiente lacustre originado por las condiciones climáticas frías-lluviosas imperantes en ese momento tuvo un carácter restringido con escaso contacto o influencia marina, debido, por una parte, al nivel relativamente bajo que presentaba el mar en ese momento ( 6 a $7 \mathrm{~m}$ como mínimo por bajo el nivel que tuvo durante la depositación del Miembro 1) y, por la otra, la acción de barrera que habría ejercido una falla norte $15^{\circ}$ oeste, reactivada previamente a la depositación del Miembro 2. Esta falla se ubica en la zona misma de la desembocadura del estero Quereo (ver Figura 9a) y habría levantado el bloque occidental, dejando expuestas, al oeste, rocas duras correspondientes a diques microdioríticos y conglomerados cuarcíferos, y rocas blandas, al este, correspondientes a lutitas negras. La acción de barrera de esta falla, sumada a las condiciones climáticas frías-lluviosas imperantes, influyeron decisivamente en la formación y características de profundidad y aislamiento del contacto directo con el mar que tuvo este ambiente lacustre.

Las condiciones geográficas, durante la depositación del Miembro 3, corresponden a un ambiente fluvial representado por un estero pequeño, el cual ocupaba parte del fondo de la quebrada, desarrollándose playas fluviales arenosas en los bordes internos de los meandros. Sobre estas playas laterales desarrollaron su hábitat diversos ejemplares de megafauna, los cuales fueron cazados y faenados in situ por cazadores recolectores paleoindios.

Las condiciones climáticas durante la depositación del Miembro 2 fueron más frías y lluviosas que las actuales en la zona. Estas condiciones fueron variando hacia climas menos fríos y lluviosos durante la depositación del Miembro 3, llegando a ser prácticamente similares a las actuales de la zona al término de la depositación de este miembro.

Con posterioridad el clima varió hacia condiciones más cálidas y secas que las existentes en la actualidad en la zona, provocándose con ello un proceso de desecamiento de los ambientes fluviales del sector de la excavación. Durante este período se generó la 


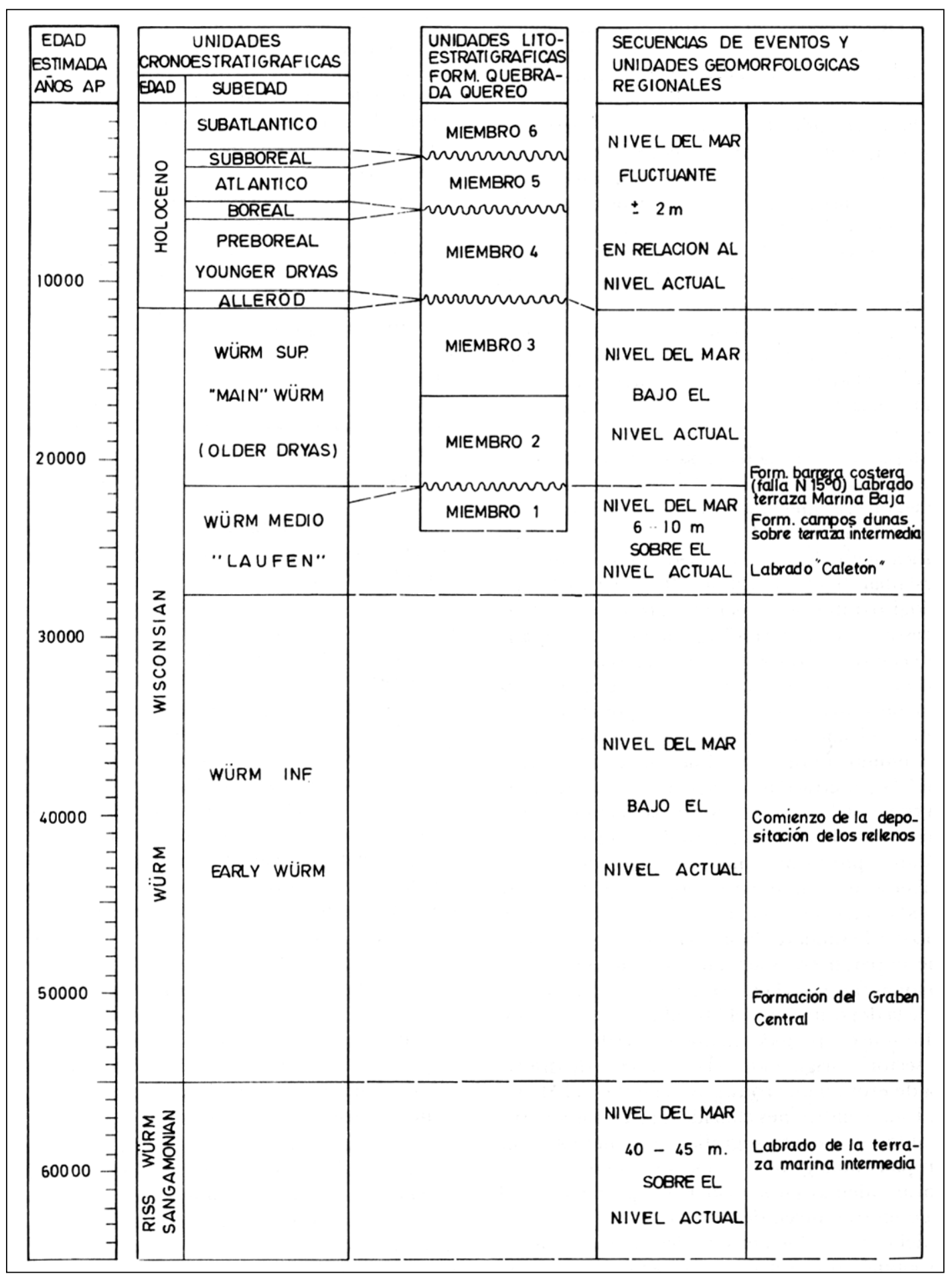

Figura 12. Correlación estratigráfica - geomorfológica de quebrada Quereo. 
superficie de discordancia de erosión y leve angular que separa el Miembro 3 del 4. Este período, a juzgar por los fechados $\mathrm{C}^{14}$ que se han realizado en el sitio de quebrada Quereo y de acuerdo a los antecedentes de la laguna de Tagua Tagua (Varela 1976a, 1976b), correspondería a la subedad definida como Alleröd, de límites cronológicos inferior y superior equivalentes a 11500 años AP y 10500 años AP, respectivamente. El comienzo de esta subedad Alleröd determina, asimismo, el comienzo de la edad holocénica o Postglacial (Olausson 1969; Varela 1976a).

La depositación de los Miembros 4, 5 y 6 se desarrolló durante el Holoceno, comprendiendo desde el Younger Dryas hasta la fecha actual. Las condiciones de depositación en el curso inferior de la quebrada durante este lapso correspondieron, en términos generales, a un ambiente pantanoso, eventualmente lagunar muy somero con algunos períodos de desecamiento parcial o total del área. El nivel del mar fue probablemente muy similar al actual, y su influencia directa en el sector de la excavación fue poco importante. Las condiciones climáticas durante la depositación de los Miembros 4, 5 y 6 fueron más frías y lluviosas que las actuales de la zona, con algunos períodos relativamente cortos de condiciones climáticas más cálidas y secas que las imperantes en la actualidad.

La depositación del Miembro 4 dentro del esquema general planteado anteriormente habría tenido lugar durante el transcurso de las subedades Younger Dryas y Preboreal (10500-6500 años AP) (Varela 1976a, 1976b). Estas habrían estado caracterizadas por la vigencia de condiciones climáticas más frías y lluviosas que las actuales. La superficie de discordancia de erosión, que constituye el techo del Miembro 4, representaría el desarrollo de un período de desecamiento del área, bajo condiciones climáticas cálidas y secas correspondientes, probablemente, a la subedad Boreal u optimum climaticum (6500-5500 años AP).

La depositación del Miembro 5 habría tenido lugar durante el transcurso de la subedad Atlántico (5500-3500? años AP), bajo condiciones climáticas parecidas a las actuales, probablemente un poco más frías y lluviosas. La superficie de discordancia de erosión que constituye el techo del Miembro 5 representa el desarrollo de un período de clima cálido y seco correspondiente, probablemente, a la subedad subboreal (3500?-2500 años AP) (Varela 1976a, 1976b).
La depositación del Miembro 6 tuvo lugar durante el transcurso de la subedad Subatlántico (2500-0 años AP), bajo condiciones climáticas que van desde un poco más frías y lluviosas hasta similares a las actuales en la zona.

Al término de la depositación del Miembro 6, las condiciones palustres fueron reemplazadas por un ambiente fluvial representado por un estero pequeño, el cual fue capaz, sin embargo, de excavar su curso encajándose en sus propios depósitos antiguos. Este cambio de nivel de base de erosión de la quebrada se debió, al parecer, a un rebajamiento, ocurrido en tiempos muy recientes, en la barrera de rocas duras existentes en la zona de la desembocadura de la quebrada. Este proceso de rebajamiento no ha culminado, continuándose en la actualidad, debido a lo cual el estero aún está en vías de obtener su perfil de equilibrio con respecto al actual nivel del mar.

\section{Correlaciones entre la secuencia de rellenos cuaternarios y las unidades geomorfológicas de la zona de Quereo}

En este capítulo se presenta un esquema tentativo de correlación entre la secuencia climático-litocronoestratigráfica definida en los depósitos cuaternarios de la Formación Quebrada Quereo y la secuencia de unidades y/o eventos geomorfológicos reconocidos en la región comprendida entre la bahía de Los Vilos y ensenada El Negro. Este esquema de correlación ha sido construido utilizándose como base la estrecha relación que existe entre el nivel correspondiente al Miembro I de la Formación Quebrada Quereo y la Terraza Marina Inferior. Ambas unidades se pueden correlacionar tanto desde el punto de vista litológico y topográfico como genético, presentando ambas prácticamente una continuidad lateral a lo largo del curso inferior de quebrada Quereo. Esta circunstancia ha permitido elaborar un cuadro de correlación que incluye las siguientes unidades y/o eventos de más antiguo a más nuevo (Figura 12):

La Terraza Marina Intermedia fue labrada por el mar en un momento en el que el nivel de éste habría superado en unos 40 a $45 \mathrm{~m}$ la altura que tiene actualmente. Esta estimación de altura, basada en la cota que tiene actualmente la terraza, podría variar de acuerdo a las modificaciones tectónicas que haya experimentado dicho rasgo morfológico después de su formación. La edad de esta Terraza Intermedia, labrada, al parecer, durante un período de alto nivel glacieustático, bajo condiciones climáticas 
cálidas y secas, ha sido asignada provisoriamente al interglacial Riss-Würm, pudiendo eventualmente extenderse al Interglacial Mindel-Riss. En la primera alternativa, la edad de término del Riss-Würm ha sido estimada en unos 65000 años AP, de acuerdo al estudio realizado en laguna de Tagua Tagua (Varela 1976a, 1976b).

Posteriormente el nivel del mar descendió a una altura similar o inferior a la actual, quedando expuesta la superficie correspondiente a la Terraza Marina Intermedia. Esta zona fue afectada a continuación por un proceso tectónico, el cual dio lugar al Graben o fosa tectónica central. Una de las fallas de dirección noreste comprometidas en la formación de este Graben prolongó su traza a través del bloque occidental, dando origen al trazado del curso inferior de la quebrada Quereo. Este proceso tectónico habría tenido lugar durante la subedad Würm Inferior o Estadial Early Würm (Flint 1957), de límites cronológicos inferior y superior equivalentes a 65000 y 27500 años AP, respectivamente (Varela 1976a, 1976b). En este momento habrían prevalecido condiciones climáticas regionales frías y lluviosas. Una vez formado el Graben Central se inició la depositación de los rellenos que lo ocupan y que constituyen la Formación Quebrada Quereo.

A continuación el nivel del mar experimentó un ascenso, alcanzando una altura del orden de $\operatorname{los} 8$ a $10 \mathrm{~m}$ por sobre el nivel que tiene actualmente. Durante esta etapa la erosión marina labró un estrecho corredor en forma de "caletón" en el área costera debilitada por la traza de la falla de dirección noreste, señalada anteriormente. Este mismo "caletón" pasó posteriormente a constituir el curso inferior del estero Quereo, luego que el mar hubo descendido gradualmente hasta una altura de unos 6 a $7 \mathrm{~m}$ sobre el nivel actual. En este momento se labró la Terraza Marina Inferior, iniciándose, además, durante su última fase, la depositación del Miembro 1 de la Formación Quebrada Quereo en el caletón emergido. Este proceso se desarrolló bajo condiciones climáticas cálidas y secas durante el transcurso de la subedad Würm Medio o Interestadial Laufén (Flint 1957), de límites cronológicos estimados en 27500 y 21500 años AP. Durante este lapso se habrían constituido además los campos de dunas antiguas ubicadas sobre la Terraza Marina Intermedia.

El término de la subedad Würm Medio (Interestadial Laufén) está representado en los depósitos de la
Formación Quebrada Quereo por medio de la superficie de discordancia que separa el Miembro 1 del 2. En este evento se reactivó, al parecer, la falla de dirección norte $15^{\circ}$ oeste que corta transversalmente la desembocadura de quebrada Quereo (ver Figura 9), originándose de esta forma la barrera de rocas duras que restringió el flujo fluvial y que dio lugar al desarrollo del ambiente lagunar restringido, que caracterizó la depositación del Miembro 2 de la Formación Quebrada Quereo.

Del período que sobreviene a continuación y que comprende el Würm Superior y Holoceno, no quedan unidades geomorfológicas de importancia que pudieran ser asignadas a las diferentes subedades comprendidas en este lapso. Durante este evento es probable que se hayan producido alternativamente procesos de estabilización regional de los campos de dunas, coincidentes con períodos de bajo nivel del mar (iguales o algo inferiores al actual), correspondiente a las subedades de clima frío-lluvioso; v.gr.: Würm Superior o Main" Würm (21500-11500 años AP); Younger Dryas y Preboreal (10500-6500 años AP); Atlántico (5500-3500(?) años AP) y Subatlántico (2500 años AP-0) (Varela 1976a, 1976b); así como períodos de reactivación o removilización de dichos campos de dunas, coincidentes con niveles relativamente altos del mar (que no superarían, sin embargo, los $2 \mathrm{~m}$ sobre el nivel actual), bajo condiciones climáticas cálidas y secas, representadas por las subedades Alleröd (11500-10500 años AP), Boreal (6500-5500 años AP) y Subboreal (35002500 años AP).

\section{Paleogeografía durante los niveles culturales paleoindios en Quereo}

El nivel cultural paleoindio sugerido como Quereo I en el sitio de la excavación tuvo su desarrollo durante la depositación de la parte alta del Miembro 1 de la Formación Quebrada Quereo; así como durante el período de formación de la discordancia inmediatamente superpuesta y el período de depositación de la sección basal del Miembro 2 de dicha formación. Este lapso corresponde fundamentalmente al transcurso de la parte superior de la subedad Würm Medio (Interestadial Laufén) (27500-21500 años AP) (Varela 1976a, b) y el comienzo del Würm Superior (21500-11500 años AP) (Varela 1976a, 1976b). Esta situación permite asignarle tentativamente una edad comprendida entre 22500 y 20000 años AP al eventual nivel cultural paleoindio Quereo I (Figura 13). 


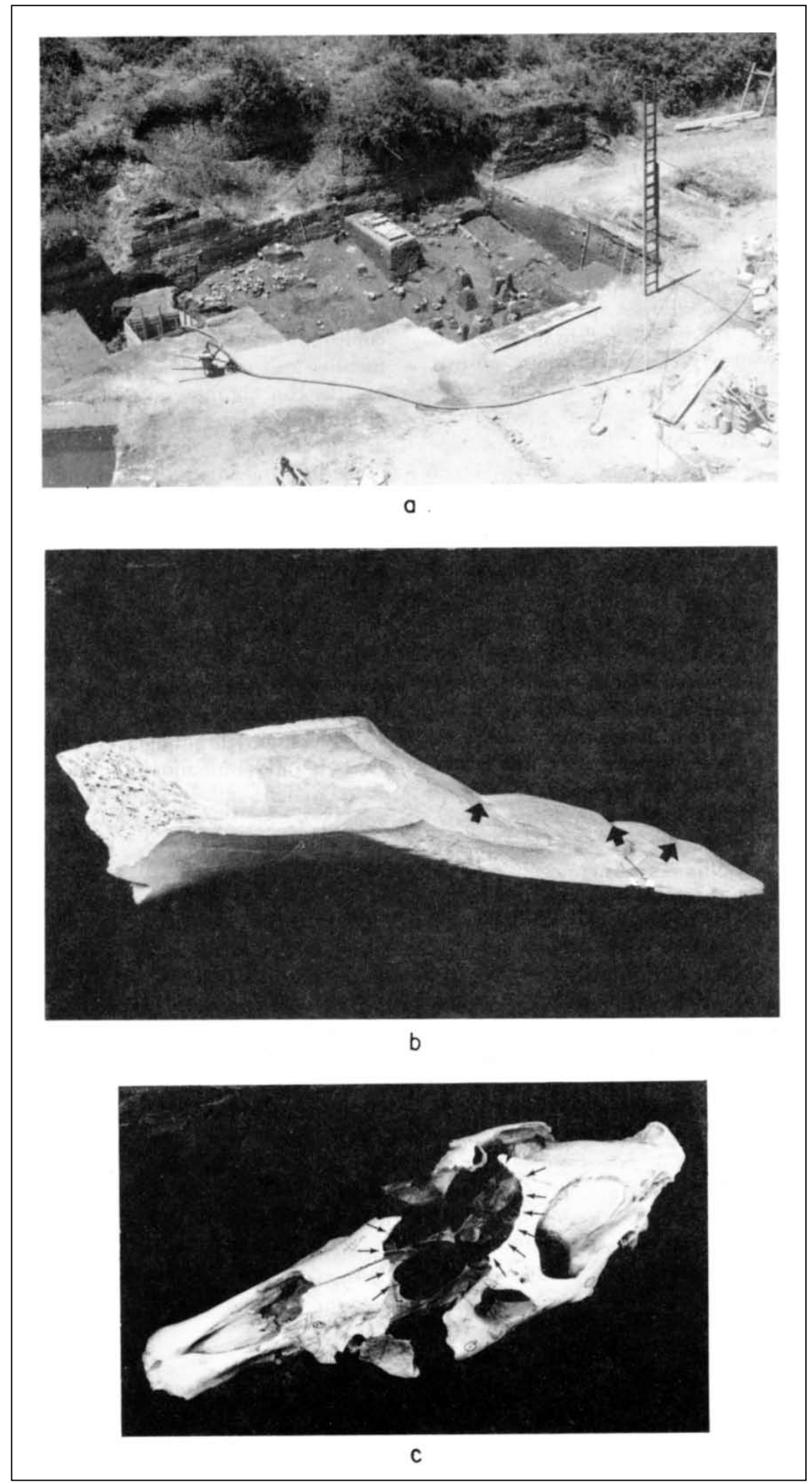

Figura 13. a) Panorama de la planta del nivel Quereo I (pre XI milenio AP); b) Artefacto óseo con tres golpes de percusión de rebajamiento (nivel Quereo I); c) Cráneo de caballo con impacto nasofrontal (nivel Quereo I). 
La paleogeografía del sector del curso inferior de quebrada Quereo durante el desarrollo de Quereo I estuvo caracterizada por un nivel relativamente alto del mar (6 a $7 \mathrm{~m}$ sobre el actual), haciendo que este penetrara por el curso inferior de quebrada Quereo en forma de "caletón" hasta el sitio mismo de las excavaciones, desarrollándose en este último punto un ambiente mixto de playa y desembocadura del antiguo estero. En este ambiente de confluencia desarrollaron su hábitat ya sea temporal o continuamente diversos ejemplares de megafauna (mastodonte, milodón, ciervo Antifer, caballo, paleolama, etc.), los cuales pudieron ser cazados y faenados in situ por los grupos paleoindios del nivel Quereo I.

El clima existente durante este período varió desde condiciones similares hasta condiciones más cálidas y secas que las actuales de la zona. Estas condiciones fueron más marcadas durante la segunda mitad del nivel, provocándose un ambiente de aridez generalizado en la zona, lo cual habría favorecido el agrupamiento de la megafauna en el sector correspondiente al curso inferior de la quebrada (sitio de excavación), debido a que este sector concentra, a modo de "embudo", gran parte de las aguas, tanto subterráneas como superficiales de una amplia región. Esta circunstancia permitió que el sector aludido presentara recursos de agua suficientes aun en los períodos más críticos de aridez regional, para sustentar con ello tanto la vegetación como la megafauna, posibilitando las actividades de caza y recolección.

El nivel paleoindio Quereo II, definido en el sitio de la excavación, tuvo su desarrollo durante la depositación de la parte superior del Miembro 3 de la Formación Quebrada Quereo, extendiéndose eventualmente hasta el período de formación de la superficie de discordancia, que constituye el techo de dicho miembro. Este período comprende el transcurso de la parte alta de la subedad Würm Superior (Estadial Main Würm; 21500-11500 años AP; Varela 1976a, 1976b) y el comienzo del Holoceno, específicamente el transcurso de la subedad Alleröd (11500-10500 años AP; Varela 1976a, 1976b). Esta circunstancia permite atribuir una antigüedad de 13000-11000 años AP para el desarrollo del nivel Quereo II, situación que está avalada además por los fechados $\mathrm{C}^{14}$ realizados (Figura 14).

Las condiciones paleogeográficas existentes en el área de la excavación durante la ocurrencia de este nivel estuvieron caracterizadas por el desarrollo de un estero de poco caudal, el cual discurría por el fondo del curso inferior de la quebrada Quereo. Este estero presentaba playas fluviales arenosas laterales sobre las cuales desarrollaron su hábitat diferentes ejemplares de vertebrados mayores (mastodonte, milodón, caballo, ciervo Antifer, etc.), siendo cazados $\mathrm{y}$ faenados in situ.

El clima imperante en la zona en este momento estuvo influido por el proceso generalizado de recuperación climática que sobrevino luego del último avance glacial del Würm (Estadial Main Würm). Durante la primera mitad del nivel Quereo II el clima de la zona fue muy similar al actual, eventualmente algo más frío y lluvioso, variando luego durante la segunda mitad a condiciones más cálidas y secas que las actuales, en especial durante el transcurso del Alleröd. Esta situación, que habría provocado condiciones regionales de aridez, favoreció, al igual que durante Quereo I, la concentración de la megafauna y con ello las actividades de caza y recolección por parte de grupos paleoindios en el curso inferior de la quebrada. Esto último, debido a la función que juega esta quebrada recolectando y concentrando las aguas superficiales y subterráneas de un amplio sector y permitiendo, en consecuencia, a modo de oasis, la subsistencia de vegetación y megafauna en su curso inferior, aun en los períodos más áridos.

Durante el período comprendido entre los niveles culturales Quereo I y II y que corresponde a gran parte del Würm Superior (21500-11500 años AP), las condiciones climáticas en la zona fueron más frías y lluviosas que las actuales, desarrollándose un ambiente de tipo lagunar relativamente profundo y rodeado por paredes abruptas en el curso inferior de quebrada Quereo. La ausencia de niveles culturales bien definidos en los depósitos que se sitúan entre ambos niveles se debería en gran parte a las condiciones paleogeográficas existentes, las cuales no permitieron el desarrollo de planicies laterales necesarias para la estabilidad de la megafauna y de las actividades de caza y faenamiento. De la misma forma, el hecho de que este período intermedio correspondiera a una etapa lluviosa habría favorecido la formación de numerosos sectores en la región con condiciones favorables para el desarrollo de megafauna y actividad humana, provocándose más bien una dispersión en una región amplia del registro cultural-paleovertebradológico en lugar de una concentración en el curso interior de la quebrada Quereo, como habría sido el caso de los niveles culturales Quereo I y II, respectivamente. 


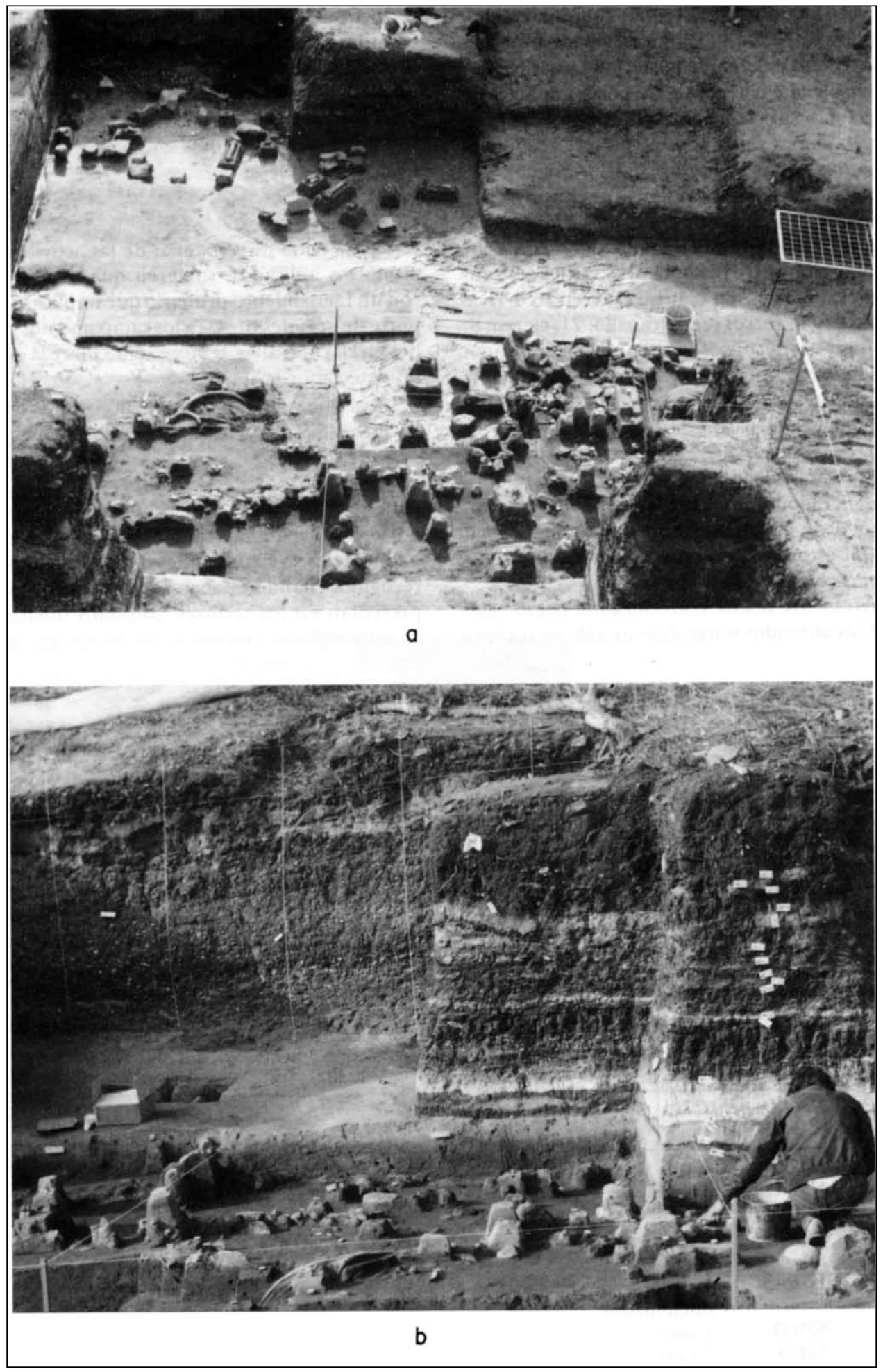

Figura 14. a) Sector de la planta excavada nivel Quereo II (XI milenio AP); b) Sector de planta y perfil nivel Quereo II. 
El bosque de quebrada Quereo es un testigo del desarrollo de singulares condiciones ecológicas, las cuales han estado relacionadas directamente con la concentración de megafauna y actividades humanas en el área. Debido a ello es conveniente reconocer los mecanismos que han dado origen a dicho bosque y en especial aquellos que determinan su permanencia a través del tiempo.

El bosque referido se ubica en la zona de confluencia de las dos ramas que constituyen el curso superior de la quebrada de Quereo, unos $500 \mathrm{~m}$ aguas arriba de su desembocadura (ver Figura 10). Esta quebrada, surcada por un curso intermitente de agua, el cual se encuentra seco en la actualidad, nace por medio de las dos ramas mencionadas en el sector alto del barranco de la cordillera de la Costa, cruzando luego el relieve correspondiente a las planicies litorales.

Las condiciones climáticas de la zona, en especial el alto índice de nubosidad y humedad relativa con frecuente formación de neblinas arrastradas, son determinantes en las formaciones vegetacionales que se desarrollan en la zona. Fuenzalida V. (1965) incluye esta área en la zona fitogeográfica mesomórfica, más específicamente en la "formación de estepa costera de arbustos y hierbas mesófitas", lo cual, en algunos sectores altos de la cordillera de la Costa, especialmente favorecidos por la abundancia de neblinas mojadoras, da lugar a formaciones arborescentes relictuales como Fray Jorge, Talinay y Cerro Santa Inés a Pichidangui.

El bosque relictual de quebrada Quereo cubre una extensión aproximada de $62000 \mathrm{~m}^{2}$, desarrollándose de preferencia en el sector de confluencia de la rama sur de la misma. Comprende diferentes especies de arbustos esclerófilos (litre, boldo, espino, maitén, lilén, etc.) y también paleoformaciones arborescentes de las cuales algunas reconocidas a través de polen y madera subfósil corresponden a especies no esclerófilas, como es el caso de Aextoxicon punctatum (olivillo) y Dasyphyllum excelsum (palo santo), lo cual estaría indicando un tipo de bosque vinculado con las comunidades relictuales de neblina (Fray Jorge y Talinay, Santa Inés, Zapallar) con claras afinidades florísticas con los bosques valdivianos del sur de Chile (Villagrán 1983).

Los factores que han influido en mayor grado en el desarrollo y permanencia del bosque, corresponden a factores climáticos y geológicos. Los primeros están representados por el nivel de precipitaciones y por el grado de humedad relativa y frecuencia de formación de neblinas que presenta la zona. Las precipitaciones que caen en la zona del bosque relictual son más bien escasas ( $262 \mathrm{~mm}$ promedio anual) y no alcanzarían, en consecuencia, a justificar por sí solas la existencia del dicho bosque. Esta situación es más evidente aún si se considera que durante el Holoceno tuvieron lugar en la zona diferentes períodos o subedades caracterizados por condiciones climáticas más cálidas y secas que las actuales de la zona (Alleröd 11500-10500 años AP, Boreal 6500-5500 años AP y Subboreal 3500 años AP). Esto haría aún más difícil explicar la persistencia del bosque relictual a base exclusivamente de régimen de precipitaciones locales (Varela 1981).

El registro, por otra parte, de un alto índice de humedad relativa, con frecuente formación de neblinas mojadoras en la zona, favorece la precipitación, con lo cual se podría eventualmente explicar el aprovisionamiento de agua en Quereo. Pero esta situación es válida más bien para otro tipo de bosque relictual ubicado en relieves prominentes de la región (Fray Jorge, Talinay, Santa Inés). Este aprovisionamiento a partir de precipitaciones de neblinas no tiene un rol importante en el caso del bosque de Quereo, debido a que éste se ubica en una hondonada, a poca altura con respecto al nivel del mar y al abrigo y, en consecuencia, de las neblinas marinas. En el pasado, el efecto de estas neblinas mojadoras tuvo menos importancia aún, puesto que la diferencia de cota entre los rellenos del Graben y la barrera topográfica que se interpone hacia el oeste fue mayor.

Entre los factores geológicos que influyen en el desarrollo y permanencia del bosque relictual de quebrada Quereo, el más importante, sin duda, lo constituye el desarrollo de una tectónica de bloques en la zona, la cual dio origen, por una parte, a la fosa tectónica correspondiente al Graben Central y, por otra, a los valles tectónicos, conectados con el Graben, que integran el sistema de drenaje de quebrada Quereo. Esta tectónica de bloques genera un tipo de relieve que controla tanto el drenaje superficial de la zona como la formación de los rellenos sedimentarios en los valles tectónicos, y en la depresión correspondiente al Graben Central. Debido a ello las aguas superficiales y, lo que es más importante aún en este caso, las aguas subterráneas son controladas por este sistema, al escurrir las primeras por la red de drenaje fluvial y por los rellenos las segundas; siendo encauzado su movimiento en este último caso, 
por las barreras rocosas impermeables laterales. De esta forma, el sistema hidrológico de la región se caracteriza por la existencia de una zona relativamente amplia de recarga que comprende el área del barranco de la cordillera de la Costa y la superficie de la Terraza Marina Alta. En dicho sector se infiltran las aguas provenientes de las precipitaciones locales, sumándoseles eventualmente aguas provenientes de condensación de neblinas y aguas aportadas desde otros sectores a través de fallas y fracturas. Estas aguas infiltradas escurren según líneas de flujo coincidentes con la red de drenaje y rellenos del curso superior de quebrada Quereo, desembocando luego subterráneamente en los rellenos del Graben Central. Estos flujos se movilizan a través de los rellenos del Graben, dirigiéndose hacia la zona de confluencia de quebrada Quereo. A lo largo de este trayecto los caudales de agua subterránea van concentrándose, y se almacenan en este último sector. Una parte de estas aguas fluye luego subterránea y superficialmente a través del corredor del curso inferior de quebrada Quereo; otra parte se desvía subterráneamente hacia el sur, dirigiéndose hacia la zona de ensenada El Negro con algunas restricciones, debido al efecto de barrera subterránea ocasionado por la actividad reciente de la falla norte $15^{\circ}$ oeste que pasa por la desembocadura de la quebrada. Una parte de las aguas subterráneas, quizás la más importante, es captada directamente por el bosque relictual en la zona de confluencia de la quebrada, constituyendo la base principal de su alimentación (Varela 1981).

En esta última zona la alta concentración de las aguas subterráneas determina que la napa se ubique a muy poca profundidad, aflorando en algunos sectores para dar origen a vertientes, aguadas o zonas pantanosas. El bosque relictual se ubica precisamente en el sector donde la napa se encuentra a escasa profundidad, inmediatamente aguas arriba del sector donde ésta aflora, generando las aguadas y zonas pantanosas que alimentan el curso inferior de quebrada Quereo.

En suma, se puede señalar que los factores climáticos locales no juegan un papel importante en la génesis del bosque; los factores geológicos, por el contrario, son determinantes en dicho proceso, especialmente cuando se trata de explicar la permanencia de dicho bosque a través del tiempo. Los factores geológicos más importantes están dados por la existencia de una zona de recarga relativamente amplia y por el desarrollo, a continuación, de una zona de escurrimiento concentrado del flujo subterráneo a modo de "embudo" con el "ápice" dirigido hacia la zona de confluencia de quebrada Quereo, que también es la zona de desarrollo del bosque. Debido a esto, el bosque recibe subterráneamente en la actualidad un aprovisionamiento suficiente de agua. Este hecho tuvo mayor relevancia durante el Holoceno, especialmente durante aquellas subedades caracterizadas por la vigencia de condiciones climáticas regionales cálidas y secas (Laufen, Alleröd, Boreal y Subboreal). A raíz del escurrimiento concentrado y efecto de almacenamiento de este sistema hidrológico, el bosque recibió al menos un mínimo de aprovisionamiento de agua, sin interrupciones, lo cual aseguró su permanencia y carácter integrador de fauna y grupos paleoindios. Durante dichos períodos críticos de sequía, la zona conformada por el bosque y el sector de vertientes situada aguas abajo, constituyó una especie de oasis independiente de las fluctuaciones de recursos a nivel regional.

Estas evidencias no son aisladas, ya que el reconocimiento geológico preliminar en otros bosques relictuales, situados también en la zona de planicies litorales (Santa Julia-Aguas Amarillas, $9 \mathrm{~km}$ al norte de Los Vilos; El Pangue, a $2.5 \mathrm{~km}$ del anterior; Quintero, a $2 \mathrm{~km}$ al noreste del pueblo homónimo), permite concluir que también son alimentados subterráneamente por aguas infiltradas en rellenos de fosas tectónicas (Varela 1981). Estos, de acuerdo a la evidencia geológica, pueden ser clasificados como bosques relictuales desarrollados en cuencas tectónicas o grabens. Estos bosques situados en los relieves altos del barranco de la cordillera costera de la región semiárida más septentrional (Fray Jorge-Talinay, Cerro Santa Inés-Silla del Gobernador-Pichidangui, Cerro La Higuera-Zapallar) y asociaciones vegetacionales equivalentes en la región árida (Cerro Moreno, Mamilla, Taltal, Paposo, etc.) han sido originados fundamentalmente por condensación de neblinas. En estos casos ha jugado un papel importante el hecho de que estos bosques y oasis de neblinas estén ubicados en relieves prominentes (los más destacados de la zona). En efecto están situados inmediatamente sobre el borde superior del barranco de la cordillera de la Costa y directamente antepuestos al mar y, en muchos casos, proyectados por medio de "puntas" hacia el oeste. Estas circunstancias favorecen, dada la dirección predominante suroeste del viento, una mayor intercepción de las neblinas y hacen más efectiva su acción "mojadora".

Estos relieves destacados corresponden a pilares tectónicos o Horst (Fray Jorge-Talinay, Santa InésSilla del Gobernador y Cerro Moreno). De acuerdo 
a los fenómenos geológicos que han determinado básicamente el origen de estos bosques relictuales de neblina, se pueden clasificar, a su vez, como "bosques relictuales desarrollados en pilares tectónicos o Horst”. Tal persistencia de recursos favorables dentro del proceso de desertización costera fue indispensable para el nucleamiento en estos ámbitos de ocupaciones humanas paleoindias y arcaicas.

\section{Las evidencias culturales paleoindias de Quereo y Tagua Tagua}

Los estudios que iniciara Bird (1938) en la región austral de Chile definieron la naturaleza de los primeros cazadores recolectores paleoindios en Chile (Período Lítico), asociados a fauna extinta, en el XI milenio AP. Posteriormente hubo un vacío de información a lo largo de casi todo el territorio chileno que sólo comenzó a cubrirse con los estudios pioneros en Tagua Tagua (Montané 1967, 1968; Casamiquela et al. 1967). Posteriores excavaciones en Quereo, situado en el territorio semiárido a $400 \mathrm{~km}$ al norte de Tagua Tagua, evidenciaron que las ocupaciones paleoindias durante el Pleistoceno Tardío se extendieron efectivamente hacia el centronorte del país (Montané y Bahamondes 1973; Núñez et al. 1983).

Estas dos primeras ocupaciones de caza asociadas a fauna extinta, señalan un singular poblamiento paleoindio circunlacustre por ahora poco conocido, con vínculos tentativos, a través de similares respuestas adaptativas durante el XI milenio AP.

\section{Eventuales episodios precursores}

En los dos sitios referidos hay evidencias de que pudieron existir ocupaciones anteriores al XI milenio AP. En efecto, en el nivel Quereo I, situado a $4.04 \mathrm{~m}$ de profundidad, en el techo del Miembro 1, se ubicaron restos de fauna pleistocénica con señales de actividad humana compatible con la caza de a lo menos un caballo y paleolama (Núñez et al. 1983). Se trata del registro de restos óseos fracturados, artefactos óseos ocasionales percutidos, huesos con marcas cortantes, vértebra de caballo perforada, cráneo de caballo con impacto nasofrontal asociado a bloques ${ }^{6}$, clasto laminar con muesca y maderos

6 Dos evidencias de huesos impactados fueron registrados en el evento nivel Quereo I: a) Un cráneo de caballo con huellas de golpe en la región nasofrontal que incluye el rebajamiento de la corteza (Figura 13c), asociado a más de ocho porciones quemados, algunos de ellos aguzados (ver Figura 13). Dos dataciones radiocarbónicas de maderos asociados a este nivel dieron las edades de $11600 \pm 190$ y $11400 \pm 145$ años AP. Estas dataciones se consideran erróneas, puesto que son sincrónicas al nivel superior (Quereo II), separado por $1.30 \mathrm{~m}$ de sedimentos diferenciados, pudiendo estar rejuvenecidas por contaminación con aguas subterráneas. En efecto, el nivel I es obviamente más temprano debido a su posición estratigráfica, y por su correlación con el sitio de Tagua Tagua se postula tentativamente que corresponde al Interestadial Laufén (Würm Medio), situado entre 25500-22000 años AP.

El nivel Quereo I presenta restos de grandes herbívoros con sus pequeños depredadores: mastodonte (Cuvieronius sp.), caballo (Equus sp.), ciervo de los pantanos (Antifer niemeyeri), paleolama sp., Lama sp., Mylodon sp. y/o Glossotherium sp., felino, cánido (zorro Dusicyon sp. ?), roedores (Phyllotis sp. y Octodon tidae), aves (Choephaga sp. y paseriformes), anuros (Bufo spinulosus sp.), así como diferentes restos vegetales.

El clima habría sido similar al actual, probablemente algo más cálido y seco, configurándose en el sector una especie de oasis donde se concentraron las especies referidas bajo el acecho de estos probables cazadores tempranos, los cuales con técnicas de encierro impactaron a lo menos un cráneo de caballo. Se presumen, además, ciertas prácticas de colecta vegetal, y uso del bosque aledaño, ya que junto a la zona de caza existía una comunidad arbórea relictual (identificación de troncos subfósiles de Dayphillum excelsum o palo santo). Después de esta fase, las condiciones mejoraron, y es probable que la fauna se dispersara en una escala geográfica mayor, al igual que los cazadores.

El registro del nivel Quereo I, en un sitio abierto de matanza similar a Tagua Tagua, revalora este último yacimiento, donde la ocupación paleoindia se constató globalmente durante el XI milenio AP (Montané 1968). Pero existieron episodios faunísticos más tempranos, puesto que Casamiquela (1976) ya había señalado la existencia de fauna fósil bajo el nivel Tagua Tagua I. Se registraron restos de mastodonte a $8 \mathrm{~m}$ de profundidad, dentro de un régimen más frío que el actual;

diseminadas en un área de $250 \mathrm{~cm}^{2}$ (cuadrante SOWO); b) Porción medial de arco neural de vértebra de caballo (S3E 10-9) con un agujero de sección rectangular en el canal medular. 
y un ciervo en el Miembro 4 (ambiente cálido), bajo el depósito excavado. Es decir, estas referencias son indicios de presencia de megafauna anterior al piso de faenamiento de Tagua Tagua I.

Por otra parte, la presencia en el registro polínico estudiado por Heusser (1983) de restos de carbón vegetal con antigüedades mayores a 11000 años AP, podría atribuirse tentativamente a actividades de caza y paraderos transitorios en las playas de la laguna de Tagua Tagua. No obstante, las evidencias de carbón vegetal podrían deberse a causas naturales. Con todo, en esta laguna se observan condiciones favorables para plantear hipotéticamente una ocupación pre Tagua Tagua I, ya sugerida a través de las evidencias de Quereo. ${ }^{7}$

\section{Ocupación paleoindia Quereo II}

En el sitio Quereo se decaparon dos niveles culturales (Quereo I y II), a través de 10 cuadrantes de $9 \mathrm{~m}^{2}$ c/u, comprendiendo un volumen de $c a .250 \mathrm{~m}^{3}$ de sedimentos, los cuales incluían múltiples evidencias faunísticas con algunos vestigios culturales, de acuerdo al carácter efímero de la ocupación humana debido al corto tiempo de caza y faenamiento desarrollado en el lugar (ver Figura 14). La reconstrucción paleogeográfica indica que un reducido grupo de cazadores de megafauna (Quereo II) se instalaron cerca de Los Vilos, junto a un desagüe fluvial reducido donde abrevaban grandes herbívoros y especies menores: mastodonte (Cuvieronius sp.), caballo (Equus sp.), ciervo de los pantanos (Antifer niemeyeri), camélido (Lama sp.), Mylodon sp. v/o Glossotherium sp., aves (Anatidae), roedores (Phyllotis sp. y Octodontomys sp.) y anuros (Bufonidae).

Los restos de animales cazados y faenados, más los testimonios humanos integran el depósito situado a $1.84 \mathrm{~m}$ de la superficie, en la porción superior del Miembro 2, constituido por arenas pardas y plásticas. Un madero aguzado registrado en este nivel se dató en $11100 \pm 150$ años AP. Durante este episodio la laguna había dado lugar a un estero de poco caudal,

7 De acuerdo al diagrama polínico de Heusser (1983), correspondiente a Tagua Tagua entre el XI al XIV milenio AP, las arboledas de Podocarpus andinus y Nothofagus dombeyii fueron significativas, colapsando después del XI milenio AP. Hasta ahora no se sabe con certeza el lugar del muestreo que dio forma a dicho diagrama, pero no parece coincidir con los niveles del sector de la excavación, aunque obviamente representa episodios que deberían involucrar a toda la cuenca. con playas arenosas en los meandros, en donde se cazaron y faenaron dos caballos simultáneamente, al parecer con bloques arrojados desde los acantilados, sin uso probable de puntas de proyectiles.

El clima era menos frío y lluvioso que en el nivel estéril inferior, algo similar al actual, de modo que se reiteró como en el nivel I un régimen de aridez, contrayendo los recursos bióticos en un locus que debió comportarse como un oasis concentrando el registro faunístico y cultural.

A juzgar por la evidencia polínica, cerca del lugar se debió localizar un bosque esclerófilo compuesto de: Lithraea, Escallonia, Maytenus, Azara, junto a indicadores palustres como Cyperaceae y Typha, de ambientes de vegas y pantanos (Villagrán 1983). Una turba dispuesta sobre el nivel II, fue doblemente datada en $9370 \pm 180$ años AP, y hace improbable otra actividad paleoindia posterior a estas fechas.

Es probable que la matanza de pocos animales de gran peso fuera suficiente para bandas poco densas; se ha constatado que estando el mar a algunos $200 \mathrm{~m}$, sólo dos conchas (Concholepas sp.) fueron registradas. La ausencia de ciertas partes anatómicas señalaría que éstas fueron trasladadas a los campamentos en lugares más secos.

La proporción entre restos óseos y rasgos culturales en general es baja. En el nivel Quereo I y I-II se verificaron 947 registros óseos (caballo: 71; ciervo: 8; mastodonte: 19; dérmicos y otros de milodontino: 407; camélido: 47; carnívoro: 1; anfibio: 54; roedor: 249; cánido: 1; aves: 62; no identificados: 75). Sólo escasas evidencias se asumen como culturales (ver Figura 13). En el nivel Quereo II se controlaron 452 evidencias óseas (caballo: 179; ciervo: 8; mastodonte: 6; aves: 8; milodontino: 172; camélido: 6 ; anfibio: 53). Un total de 50 restos culturales se han verificado en este nivel, en especial a base de rasgos óseos (Tabla 1 y Figura 15):

Los artefactos líticos tienen filos alterados normalmente sólo en un lado recto, de modo que un mismo espécimen puede mostrar filos no alterados e inversamente una contraparte usada. Este patrón de uso de filo ocasional sólo exigía una leve aplicación, ya que una vez desgastados, los litos eran reemplazados por otros.

Las acciones cortantes son mayoritarias, y se verifican por la selección intencional de litos con filos y por 


\begin{tabular}{|c|c|c|c|c|c|}
\hline \multicolumn{6}{|c|}{ A. Especímenes con marcas cortantes: } \\
\hline \multicolumn{2}{|r|}{ Nivel Quereo II } & \multicolumn{2}{|c|}{$\begin{array}{c}\text { Nivel Quereo II-I } \\
\text { (Depósito intermedio) }\end{array}$} & \multicolumn{2}{|r|}{ Nivel Quereo I } \\
\hline N3E0 & $: 3$ casos & NOE0 & $: 2$ casos & S3E8 & $: 3$ casos \\
\hline N3E3 & $: 5$ casos & SOE3 & $: 6$ casos & SOE0 & $: 4$ casos \\
\hline S3E0 & $: 4$ casos & & & S3E3 & $: 1$ caso \\
\hline S3E3 & : 5 casos & & & S3E10 & : 5 casos \\
\hline S3E8 & $: 2$ casos & & & NOW0 & $: 2$ casos \\
\hline Test 3 & $: 1$ caso & & & & \\
\hline \multicolumn{6}{|c|}{ B. Especímenes con percusión, desbastamiento, pulimento y cicatrices de uso: } \\
\hline \multicolumn{2}{|r|}{ Nivel Quereo II } & \multicolumn{2}{|c|}{$\begin{array}{c}\text { Nivel Quereo II-I } \\
\text { (Depósito intermedio) }\end{array}$} & \multicolumn{2}{|r|}{ Nivel Quereo I } \\
\hline N3E0 & $: 1$ caso & S0E0 & $: 1$ caso & S0E0 & $: 2$ casos \\
\hline N3W0 & $: 3$ casos & NOE0 & $: 1$ caso & S3E10 & : 3 casos (un impacto) \\
\hline N3E3 & $: 2$ casos & S0E3 & $: 1$ caso & sow0 & : 3 casos (un impacto) \\
\hline Pozo 3 & : 1 caso (un impacto) & & & & \\
\hline S3W0 & $: 1$ caso & & & & \\
\hline S3E0 & $: 1$ caso & & & & \\
\hline S3E8 & : 2 casos & & & & \\
\hline Testigo & $1: 1$ caso & & & & \\
\hline
\end{tabular}

Tabla 1. Registros óseos de Quereo modificados por intervención humana.

las marcas tajantes advertidas en huesos específicos de los animales faenados. El carácter transitorio reflejado en la inestabilidad de las actividades y los artefactos usados sugieren que sólo se realizó con un faenamiento primario que implicaba el transporte de grandes partes anatómicas a los campamentos establecidos en las cotas altas, seguramente sobre la quebrada, no detectados hasta ahora.

Para que este patrón de uso de artefactos ocasionales ocurra se requiere de una fuente abundante de litos con filos naturales. En efecto, ambos barrancos de la quebrada ofrecían suficiente cantidad. En algunos instrumentos laminares se advierte un patinado por exposición a los agentes ambientales, lo cual significa que algunos litos fueron recogidos cuando estaban expuestos. Por esta razón presentan en los sectores utilizados huellas de microastillamiento y socavado por uso (muescas), con ausencia de patinado, evidenciado con un color más oscuro el cual contrasta con el resto del artefacto.

Por otra parte, las características de las rocas de la zona no son adecuadas para la aplicación de técnicas de percusión y presión, ofertando más bien filos naturales resistentes y de mayor eficiencia que los logrados con tecnología más sofisticada. En efecto, el área se caracteriza por un déficit de rocas adecuadas (p.e., sílices), predominando las rocas intrusivas así como las lutitas y la arenisca. El recurso lítico más frecuentemente usado en los niveles Quereo II y I proviene de un dique de 25 a $30 \mathrm{~m}$ de espesor que aflora en el sector. Se trata de una roca de color verde-azulado, de tamaño de grano microcristalino, a veces casi afanítica. Debido a su composición y textura se puede clasificar como una microdiorita o diabasa. Sus propiedades señalan que se trata de una roca relativamente frágil y de poca dureza, que al fracturarse, sin embargo, produce cantos y aristas cortantes.

En general, cuando los restos óseos de estos depósitos presentan modificaciones, estas pueden deberse a: 1) Interferencia de procesos biológicos: marcas de roedores y carnívoros (Figura 16); 2) Procesos naturales como modificaciones por alternancias de humedad-secamiento-congelamiento, transformaciones químicas, arrastre riguroso (evidencias negativas en Quereo); 3) Interferencia cultural por aplicación de procesos tecnológicos. Aunque hay leves diferencias, 




Figura 15. Evidencias culturales del nivel Quereo II (XI milenio AP); a) Miembro de caballo con evidencia de uso de artefacto cortante (Quereo II); b) Artefacto de miembro de caballo con extremo aguzado modificado (Quereo II); c) Fragmento distal de artefacto óseo con extremo aguzado y pulido (Quereo II); d) Lasca con ondas de percusión (Quereo II).

en ciertos casos minoritarias entre estas variables, la identificación cultural de las modificaciones se ha ratificado con procedimientos de laboratorio y pruebas experimentales (p.e., huesos fracturados o raídos después del proceso de mineralización e identificación de patrones de fractura en huesos frescos, diferentes a los fosilizado). ${ }^{8}$

Hay determinadas fracturas que son producidas por agentes naturales a través de meteorización. En efecto, todo hueso fresco a partir de su depositación

8 Bindford habla de una pieza ósea de Quereo, referida como un registro de Tagua Tagua, que fuera comentada por Canby (1979), a raíz de su visita al sitio como veedor de la National Geographic Society. Se trata de un miembro de caballo con marcas paralelas anchas (ver Figura 16), correspondientes a dientes de un predador, tal como lo reconoce Bindford. No obstante, queda fuera de duda que tanto en Tagua Tagua como Quereo hay artefactos óseos inequívocos, verificados con análisis de laboratorio y experimentación (ver Figuras 15 y 16). comienza a deshidratarse y experimenta la pérdida del calcio. También a través del tiempo el intercambio molecular permite el proceso de fosilización. Estos factores presentan distintas propiedades mecánicas, según sean las características de su registro. Si las evidencias han quedado expuestas, aparecen trazas de agrietamiento como líneas de fisuras, orientadas a lo largo del eje de las diáfisis. Tal patrón es distinto a las fracturas traumáticas. Cuando éstas ocurren en huesos descalcificados y/o deshidratados, las evidencias se advierten en bordes escalonados, debido a que las ondas que difunden la fractura son interceptadas por las fisuras y grietas precedentes.

Las fracturas traumáticas son mayormente generadas por la intervención humana, aunque las excepciones, tales como pisoteo de animales, efecto de trituración por carnívoros, etc., deben también tenerse en cuenta, aunque cuando ocurre no son numerosas en la colección y no muestran categorías debidamente intencionadas o formalizadas. 


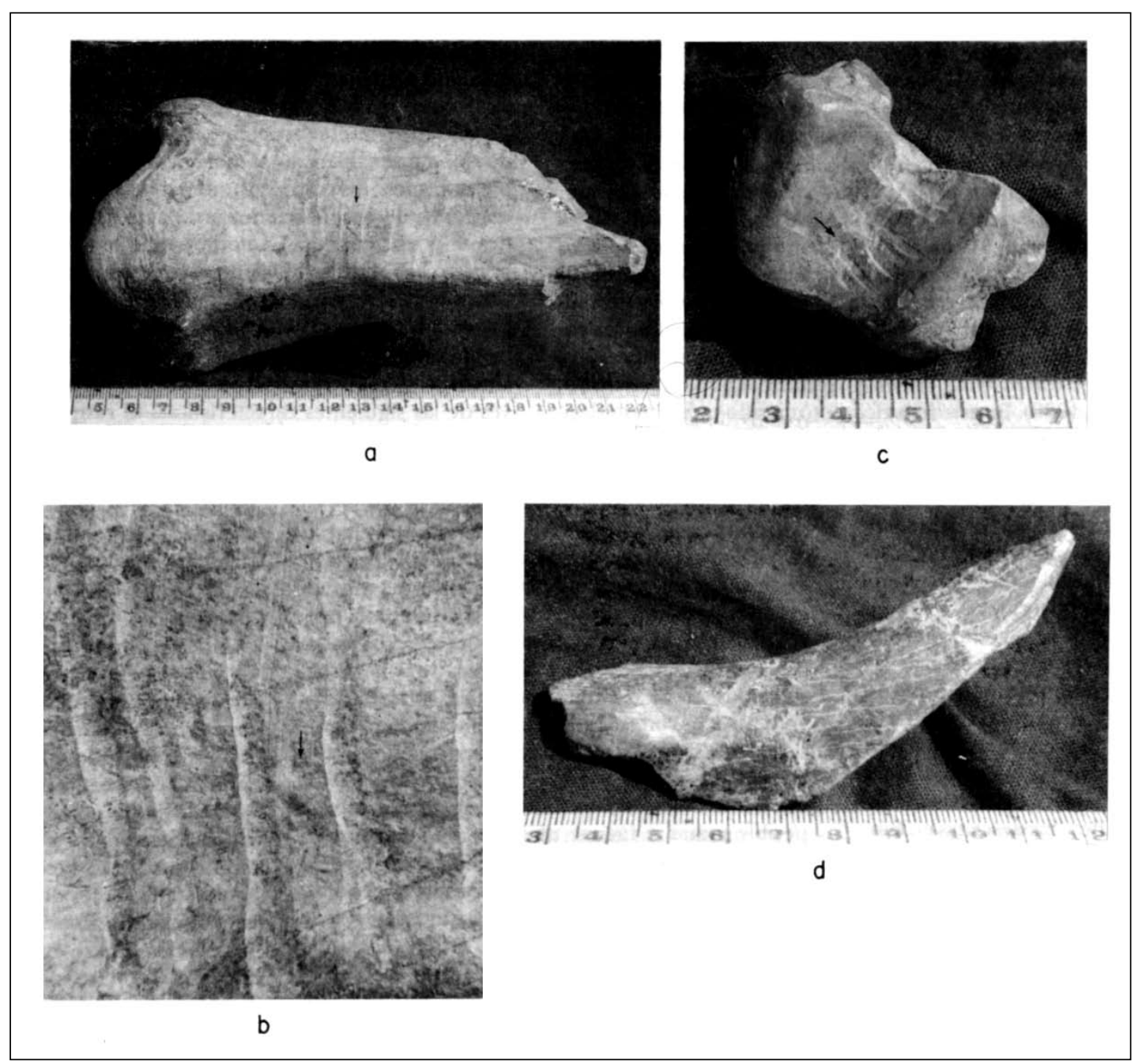

Figura 16. Evidencia de Quereo II (XI milenio AP). a) Miembro de caballo con marcas paralelas de dientes de predador; b) Detalle ampliado de la foto anterior; c) Articulación de caballo con marcas paralelas de dientes de predador; d) Artefacto óseo con extremo aguzado modificado y pulimento.

Una evidencia común tanto en Quereo como en Tagua Tagua, en huesos modificados por causas culturales son los cortes tajantes derivados del paso de artefactos líticos, con lascas modificadas y litos de filos naturales. Otras evidencias de líneas finas como estrías o de superficies abrasivas se han registrado en Quereo, aunque no se ha identificado una función específica por ahora. No obstante, en otros yacimientos de Norteamérica han resultado de la acción de raspado sobre un determinado espécimen. Por otra parte, superficies pulidas también presentes en Quereo y en Tagua Tagua parecen no ser extremos o bordes finiquitados de un artefacto, sino más bien evidencias de desgaste por uso intensivo.
En el sitio Old Crow (Irving et al. 1973), los ensayos experimentales han demostrado que los huesos arqueológicamente más recientes se fracturan en líneas paralelas o perpendiculares a la estructura celular. Los huesos frescos, por su parte, presentan, en términos generales, líneas de fracturas curvas y diagonales. En el caso del sitio referido, las fracturas de huesos mamut presentan el patrón antes señalado (prefosilización), del mismo modo como los casos ocurrentes en las fracturas de los niveles Quereo I, II-I y II, logrados por actividad humana. Es poco probable que algún mamífero carnívoro pueda fracturar una extremidad ósea de mastodonte y aun de caballo robusto. Por otro lado, en Quereo el congelamiento, 
arrastre entre rodados (hay molares in situ) y presión del depósito, etc., son todas causas desestimables. Cuando estos fenómenos ocurren en otros sitios, la mayoría de los huesos se afecta y no sólo algunos como ocurre en estos casos, en que las modificaciones son derivadas de la actividad humana.

Por otra parte, no se han registrado evidencias de agentes naturales capaces de fracturar el cráneo de caballo del depósito no disturbado del nivel Quereo I. En este caso el impacto nasofrontal produjo la muerte instantánea del animal adulto $(55 \mathrm{~cm}$ de longitud total del cráneo), con uno o más golpes bien dirigidos, que no afectaron la caja craneana, dando lugar a un hundimiento y ruptura diferencial. La asociación de los fragmentos óseos derivados del impacto con los bloques líticos esparcidos en el contorno señala una actividad humana como causa de estos impactos.

Normalmente se utilizan dos vías diferentes para romper y rebajar un hueso: la fractura directa y el lasqueo por percusión. Se ha constatado que para obtener especímenes rebajados con lasqueo se preferían huesos largos o miembros de paredes gruesas de mastodonte o mamut. Se incluyen también a aquellos huesos de caballos, paleolamas y bisontes robustos, más adecuados para su transformación en instrumentos (Bonnichsen 1978). En este sentido, tanto caballo como mastodonte aportan Quereo la principal materia prima utilizada en los escasos artefactos formatizados recuperados. Además de la fractura espiral destinada a lograr porciones para preparar artefactos, es posible que cuando los grupos fueron demográficamente más densos, los huesos se hayan fracturado con mayor frecuencia para la extracción de médula. Este tipo de evidencia no es común en Quereo, en donde, por el contrario, llama la atención la presencia de huesos cuya médula no ha sido utilizada. Esto parece ser común en grupos de baja densidad, de modo que el mayor énfasis en fracturas se orientó a la preparación de artefactos de uso ocasional, siendo la fractura espiral la más típica. De acuerdo a Bonnichsen (1978) y Stanford (com. pers. 1978), al colocar una tibia de caballo u otra similar sobre un rodado o bloque lítico, el percutor (preferentemente rodado) se aplica sobre un punto de impacto en la zona medial. La fractura se extiende sobre el lado dorsal y se desprende el ventral, dando lugar a una identación curva y de ángulo obtuso, correspondiente al punto de impacto. Este procedimiento permite la separación de la tibia de una porción completa de epífisis con escasa porción medial. El extremo opuesto presenta la diáfisis con un tercio del hueso largo rematado en extremo apuntado o afilado. Cuando la fractura es violenta, se desprende la porción medial del hueso largo de ambos extremos (diáfisis y epífisis), con la cual se obtiene un trozo separado apto para adecuarlo si es necesario con algunos golpes adicionales, como artefacto de uso inmediato. En el caso de Quereo, varios artefactos provienen del impacto de fractura espiral, en especial aquellos que muestran identación curvada, y pulimento de uso derivado, al parecer, de actividades de carneo, algo similar a las evidencias descritas en Bonnichsen (1978).

Una de las ventajas de la fractura espiral es que produce artefactos ocasionales que no requieren de procesos complejos de formatización. Normalmente, el extremo activo queda aguzado y/o afilado y se pueden rebajar (filo) con golpes adicionales de percusión, según consta en un caso de Quereo ya señalado. Otra de sus características es que los bordes y extremos, una vez usados, tienden a pulirse, y otros presentan un bisel sobre el fin proximal. Se ha criticado que estas evidencias tecnológicas en yacimientos pleistocénicos de poca profundidad pudieran ser el resultado de reutilizaciones por parte de ocupaciones muy posteriores. Tanto la pátina ósea como la estratigrafía sellada sin disturbaciones y la profundidad de los yacimientos de Quereo y Tagua Tagua excluyen esta posibilidad.

Hemos determinado que la mayor frecuencia de fracturas se registran en huesos largos frescos a través de las siguientes características: a) rastros de la zona de impacto; b) superficie de fractura diagonal y/u oblicua a la superficie externa de la masa compacta del hueso largo; c) tendencia a bordes fracturados de contornos curvilíneos, d) los extremos proximales y distales de la zona fracturada son algo redondeados; $\mathrm{y}$ los frentes de las fracturas suelen rematar en las epífisis o algo antes.

En los huesos largos de caballo de Quereo no se reconoce el patrón de fracturas transversales que producen rupturas perimetrales variables con tendencia a la separación tajante o total. Más bien se han identificado fracturas longitudinales debido a que el impacto ha producido rajaduras por la diáfisis o en el opuesto, dejando fracturas orientadas de manera rectilínea y/o curvada, en el sentido del eje del miembro. Sin embargo, la mayoría de los casos observados se afilian a las fracturas en espiral, típicas para los huesos largos frescos depositados 
y modificados antes de que sean afectados por los fenómenos de fosilización. De acuerdo a los resultados experimentales se estima que la tecnología aplicada en Quereo corresponde al impacto sobre miembros óseos dispuestos sobre yunque. Hay bloques líticos asociados al nivel de fauna. Así, la dirección y potencia del impacto tensiona y comprime por el efecto de contragolpe, facilitando el resultado esperado.

En suma, el hueso como materia prima para artefactos es de suma eficiencia para cazar y faenar grandes herbívoros. Así, diversos grupos de cazadores pleistocénicos, de manera independiente, pudieron utilizar artefactos óseos de uso ocasional como subproducto de la caza, como en Quereo. Esto habría sido más común si no se contaba con recursos mejores. En efecto, Stanford (1978), de acuerdo a sus propios registros y apoyado por procedimientos experimentales, ha concluido que incluso: "pudo ser posible matar y faenar un mamut enteramente sin instrumentos líticos”. Respecto a las marcas de cortes registrados en Quereo y en Tagua Tagua, éstas se vinculan con etapas de desollado y faenamiento o descarnamiento. Son algo frecuentes en huesos largos de extremidades, por cuanto allí se logra el desmembramiento de presas específicas. Estas prácticas parecen tener una amplia distribución, tal como ocurre en Taima Taima. En efecto, un pequeño mastodonte estudiado por Bryan (1978), que contenía en la región pelviana una punta lítica del patrón Jobo, ocupó un área de dispersión correspondiente a un esqueleto casi completo. Las presas restantes: cráneo, vértebras cervicales, algunas dorsales y miembro derecho, se colocaron al parecer fuera del sector de faenamiento. En el lugar de despresamiento se localizó un húmero, que presenta seis marcas tajantes, además de una costilla con marcas evidentes, determinadas como evidencias culturales por el tercer autor.

\section{Ocupación paleoindia Tagua Tagua I}

Durante las excavaciones de Montané (1968), un sector dominante del sitio Tagua Tagua I fue excavado en un volumen aproximado de $30 \times 10 \mathrm{~m}$, hasta una profundidad variable entre $2.35 \mathrm{a} 2.67 \mathrm{~cm}$ de profundidad, hasta exponer un paleosuelo carbonoso correspondiente a la base del Miembro 6 de la Formación de Tagua Tagua. Bajo este paleosuelo se dispone el techo de las arcillas gris-verdes de la parte superior del Miembro 5. Los restos faunísticos y culturales provienen de cerca de $500 \mathrm{~m}^{3}$ de sedimentos controlados a través de decapado de dos niveles culturales superpuestos. Aproximadamente se registraron 15 artefactos líticos sujetos a taxonomía, más varias lascas usadas, desecho lítico, huesos marcados, artefactos óseos, percutores líticos, entre otros, que configuran no más de 50 evidencias culturales inequívocas (Figura 17).

Tres dataciones $\mathrm{C}^{14}$ apoyan esa asociación de megafauna y hombres, tal como ocurrió en Quereo II en depósitos no alterados: 11380 320 AP, $11320 \pm 300$ AP, $11000 \pm 170$ AP. Se ha registrado ciervo juvenil de los pantanos (Antifer sp.), mastodonte juvenil (Cuvieronius humboldtii), caballo robusto juvenil (Equus sp.), cánido (¿zorro?), ranas, coipos, ratones, aves acuáticas, anfibios como Leptodactilido, Calyptocephalella (caudiverbera) y peces (Casamiquela et al. 1967; Montané 1968, 1976).

El paleosuelo donde se estableció el faenamiento habría estado sometido temporalmente a condiciones subaéreas, cuando el lago se restringió hacia el centro de la cuenca, durante la subedad Alleröd, caracterizada por un clima templado a cálido y escasas lluvias. De tal modo que en esta playa lacustrepantanosa, con inundaciones irregulares, ocurrió la caza y faenamiento de a lo menos mastodonte y caballo, cuyos despojos quedaron asociados a fauna depredadora. Los cazadores impactaron con bloques el cráneo del proboscídeo (ausencia de uso de puntas de proyectil), tal vez con tácticas previas del acorralamiento con fuego (Montané 1976). El faenamiento fue in situ, puesto que hay huesos astrágalo y calcáneo de caballo con marcas de pasos de cuchillo, llevándose ciertas presas hacia los campamentos emplazados probablemente en zonas más secas. El registro lítico de Tagua Tagua es más elocuente: cuchillos bifaciales presionados (uso de obsidiana andina), lascas laminares bilaterales de borde alterno, raspadores de lascas con retoque unifacial similares a los usados en Cueva Fell (Patagonia). Entre los artefactos ocasionales se destacan lascas monofaciales con huellas de uso, que fueron calentadas (o sus núcleos) para facilitar el retoque o su desprendimiento. No faltan toscos percutores y machacadores de granito e implementos de hueso como punzones pulimentados y huesos de caballo usados como percutores y retocadores, estos últimos vinculados con el reafilamiento y biselamiento de los artefactos que eran usados en el faenamiento, ya que se constataron desechos derivados de percusión in situ. Corpúsculos de carbón y huesos quemados 



b
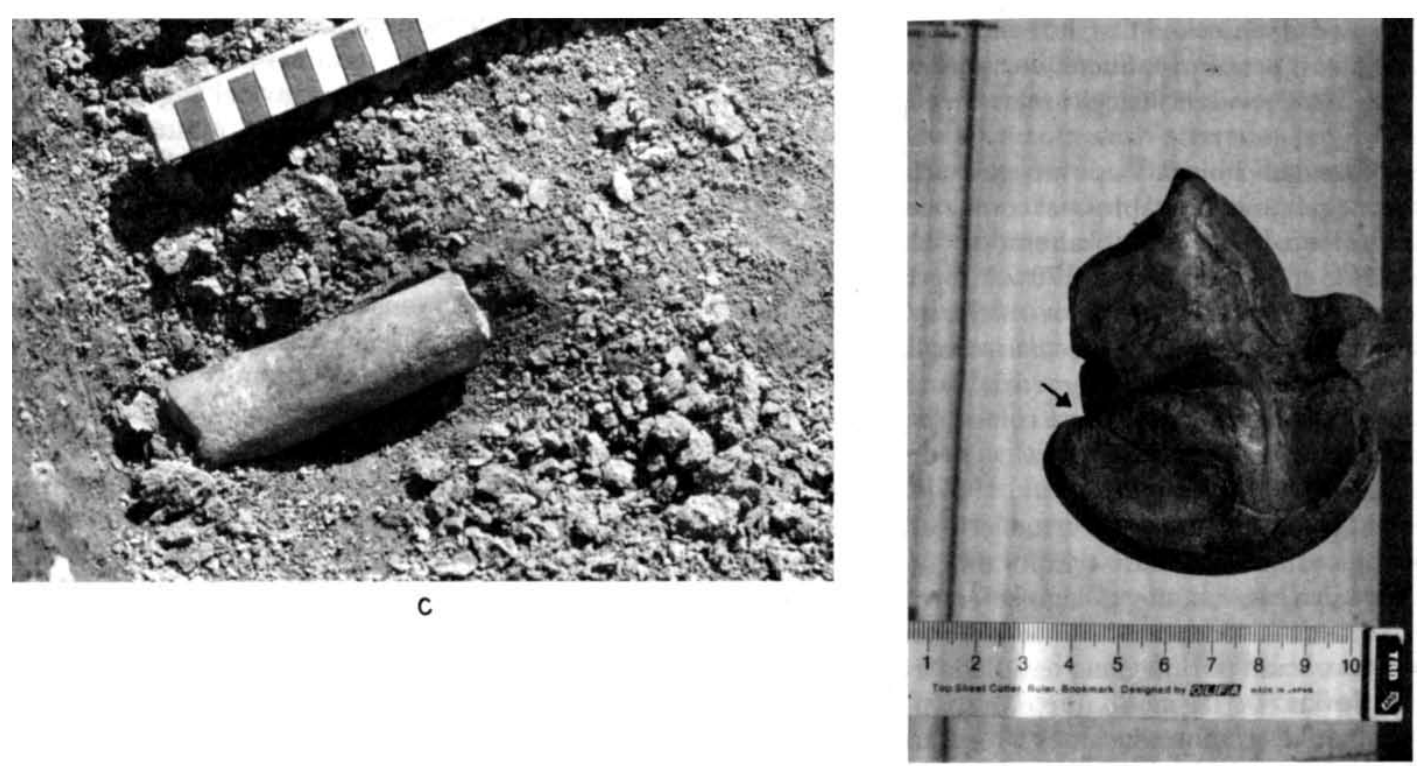

d

Figura 17. Evidencias culturales del nivel Tagua Tagua I (XI milenio AP). a) Lasca de sílice con presión lateral de uso cortante; b) Cuchillo-raedera de obsidiana; c) Retocador de miembro de caballo in situ. Foto gentileza de J. Montané;

d) Astrágalo de caballo con huella de cuchillo. Fotos a, b, d: gentileza del Museo Nacional de Historia Natural, Santiago. 


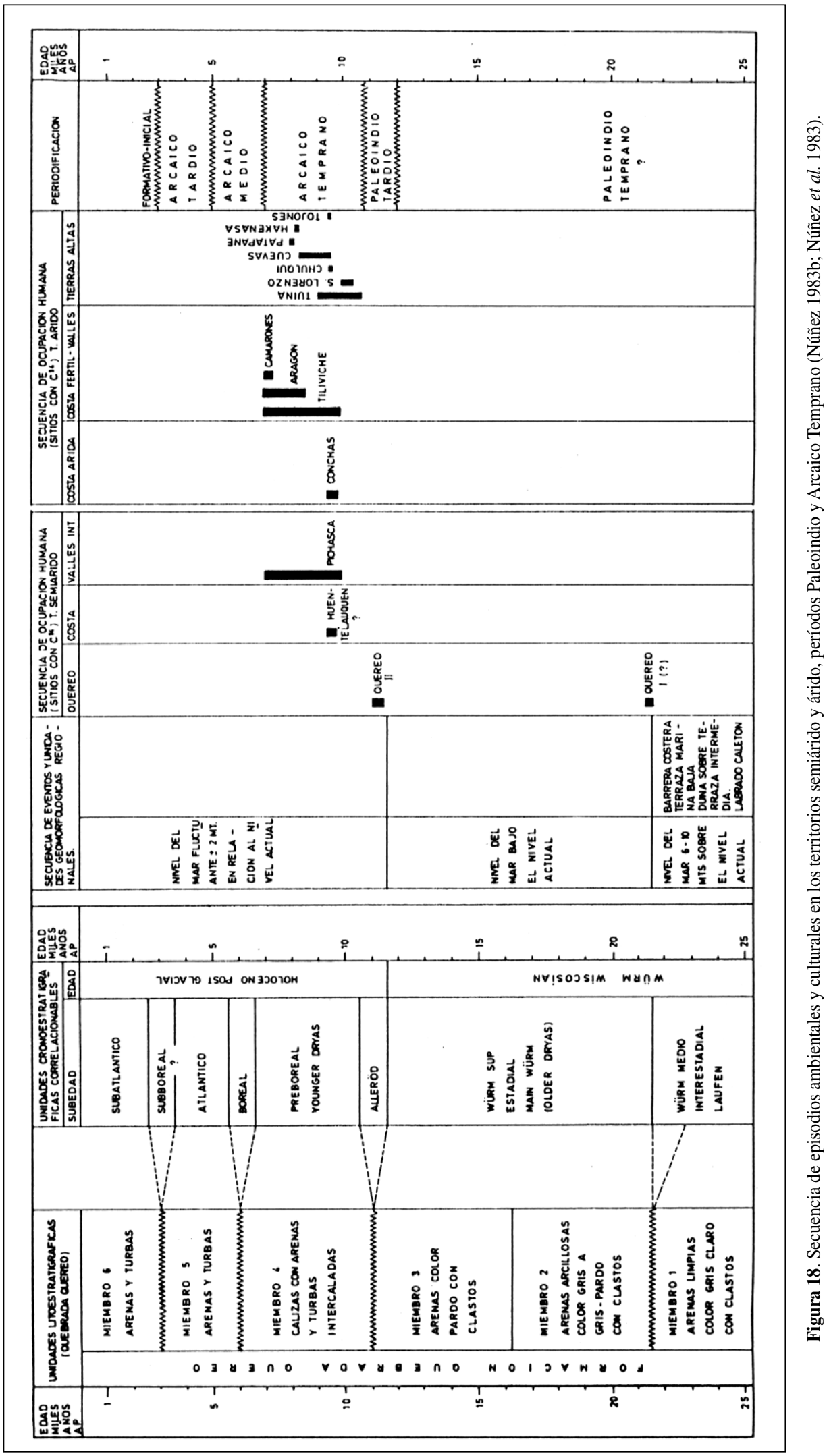




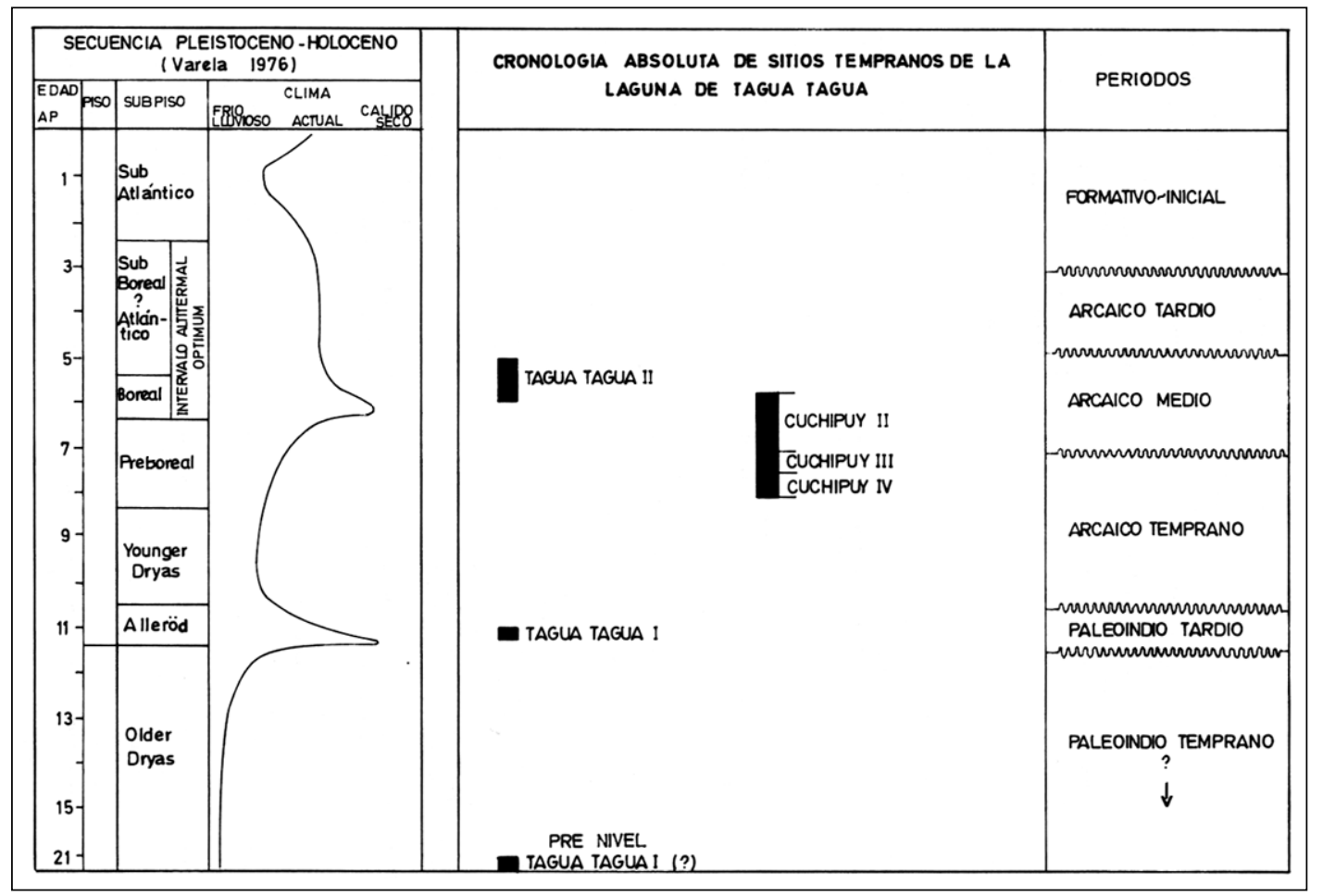

Figura 19. Secuencia de episodios ambientales y culturales en la laguna de Tagua Tagua.

indicaron presencia de fogones cercanos y de una probable merienda cerca del lugar.

La caza de mastodontes, de acuerdo a la etología de los elefantes, pudo efectuarse cuando permanecían en el agua, sin vínculos al acto mismo de abrevar, como pudo ocurrir con los otros mamíferos del techo del Miembro 5 (Tagua Tagua I) (caballo, ciervo y cánido) más aproximados más temporalmente. Como el piso debió ser fangoso, incluso con eventuales depósitos efímeros de agua entre 20 a $30 \mathrm{~cm}$ de acuerdo a una evidencia ósea expuesta a desgaste por la intemperie, es probable que la presencia de abundantes restos de peces (escamas, vértebras y huesos mínimos) señalan grandes charcos, entre los cuales se empantanaron y luego se golpearon los cráneos de los animales de mayor peso (Casamiquela 1976). Es probable que algunos miembros de caballo y ciervo se hayan movido algo del lugar de caza, donde a lo menos se impactó un mastodonte y se desolló un caballo a juzgar por la presencia de su astrágalo y calcáneo izquierdo, con cortes que sugieren que estaban articulados en el momento que se inició el faenamiento. Las actuales técnicas etnográficas de desollado de cuero y seccionamiento de tendones de las patas son coherentes con estas evidencias (Casamiquela 1976).
Aunque hubo dispersión y fragmentación por la acción de los cazadores y predadores en un ambiente de playa lacustre de aguas tranquilas, hay un déficit deliberado de las cajas de los cuerpos, debido a lo cual se asume que ciertas presas se llevaron a lugares más secos (campamentos). De todos modos, la presencia mayoritaria de animales juveniles indica muertes no naturales.

De todas las evidencias, el caso del mastodonte es el más revelador, por cuanto parece que se faenó donde fue abatido, puesto que sus huesos están cerca de su posición original. En efecto, se registraron dos mitades de pelvis y cráneo, este último girado en $180^{\circ}$ en relación a la pelvis. Se suman dos escápulas, mandíbula y otros restos cercanos, restando algunas presas sacadas fuera del lugar.

El impacto sobre el cráneo del mastodonte debió ser efectivo, lo suficiente para abatir un macho juvenil con una altura de $2.50 \mathrm{~cm}$ a nivel de la curva lumbar. Si fue acorralado con fuego o con perros, aun no se puede esclarecer. Hay registro de un cánido parecido al zorro colorado actual o culpeo (Dusicyon culpaeus Molina), pero las observaciones de L. Parodi, del Museo de La Plata, lo afilia tentativamente al género Canis. Si este Canis no era 
doméstico y actuó como perro salvaje o zorro, tal vez no ayudó a la cacería, pero pudo satisfacerse con aves acuáticas y anfibios, y fallecer aquí de manera accidental (Casamiquela 1976). Aún no es posible asegurar cuántos animales permanecieron en este piso de faenamiento. Como se ha dicho, el drenaje del actual canal artificial ha excavado y acarreado múltiples evidencias en Tagua Tagua, de la misma forma como el curso fluvial de quebrada Quereo erosionó gran parte del piso de matanza del nivel Quereo II.

Durante el transcurso de este episodio el clima en Tagua Tagua era más bien cálido y poco lluvioso (Varela 1976), con una cubierta vegetacional compuesta de un sensible crecimiento de ChenopodiaceaeAmaranthaceae, concordante con la vigencia de un ámbito cálido y seco (Heusser 1983). Paralelamente se ha advertido una escasa frecuencia o descenso de Nothofagus acorde con una escasa presencia de Compositae y Graminae, por lo que se ha señalado que la evaporación habría aumentado a la par con la temperatura.

Con estos antecedentes se ha estimado que los mastodontes tenían poca provisión de alimentos en relación al período anterior al XI milenio AP. De tal manera que se concentraron en un espejo de agua más restringido, siguiendo, al parecer, el patrón de Quereo, es decir, un refugio tipo oasis que favoreció la intensificación de las matanzas. Heusser (1983) acepta que la presencia dominante de Chenopodiaceae-Amaranthaceae enfatiza el dominio de un ambiente seco, adverso a las actividades paleoindias, disminuyéndose críticamente la presión demográfica. No obstante, pensamos que en términos de concentración del registro arqueológico, la situación de oasis, al contrario, permitió una extraordinaria oportunidad para intensificar las actividades de caza $\mathrm{y}$ faenamiento en un lugar restringido.

De acuerdo a los datos disponibles, y a la falta de fuentes comparativas, fuera del territorio señalado, las conclusiones son obviamente tentativas (Figuras 18 y 19). Es posible que hayan ocurrido episodios culturales anteriores al XI milenio AP, sobre los cuales no hay aún evidencias muy explícitas. Al observar ambos sitios, en lo concerniente a las ocupaciones bien constatadas de dicho milenio, queda la impresión de que configuran episodios comunes dentro de un régimen adaptativo que reorientó a los cazadores emigrantes a la explotación de los ricos recursos disponibles en torno a lagos pleistocénicos emplazados en cuencas bajas no andinas. Estas condiciones se habrían extendido desde Quereo al sur, a lo largo de una cadena de cuencas intermontanas y subandinas emplazadas en la cercanía del llamado Valle Longitudinal de Chile. Estos recursos localizados en ambientes subandinos concentraron densas manadas de herbívoros pleistocénicos, los que a su vez estimularon una amplia distribución de sus cazadores. Tal dispersión quedó limitada durante las etapas de sequías, en donde hombres y animales se restringieron en sectores más estrechos, estimulándose cacerías intensivas, en especial durante el comienzo del régimen de mayor aridez del postglacial, correspondiente al Alleröd (Varela 1976).

Las ocupaciones de Tagua Tagua y de Quereo presentan algunas similitudes diagnósticas: a) son sitios abiertos de matanza en torno a ambientes acuáticos reducidos o disminuidos; b) tienen similares técnicas de caza con impactos de bloques sobre cráneos; c) cazan animales similares (mastodonte, caballo, ciervo), trasladando presas fuera del sitio; d) las prácticas de faenamiento ocurren in situ, con huellas del paso de cuchillos en las zonas óseas críticas; e) hay similares artefactos óseos de uso ocasional, elaborados a partir de los subproductos de la caza; f) los episodios ambientales son equivalentes y las dataciones radiocarbónicas sincrónicas. Se incluye un patrón de dispersión de huesos por acción antrópica y predadores menores (anuros, aves, roedores), incluyendo la superposición de ocupación arcaica y baja frecuencia de artefactos líticos. Fuera de estas relaciones, es poco lo que sabemos sobre la naturaleza de este patrón adaptativo localizado en torno a ambientes acuáticos a fines del Pleistoceno. La carencia de datos para comprender su mayor equipamiento, estilos de vida y hábitat específicos no nos permite por ahora discutir estas evidencias en una escala mayor. La actual investigación se conduce en una dirección sin criterios apriorísticos, a lo largo de pocos sitios-claves que puedan representar los problemas más potenciales del país desde nuestra perspectiva multidisciplinaria.

Antofagasta, diciembre de 1983. 


\section{REFERENCIAS CITADAS}

BIRD, J., 1938. Antiquity and migration of the early inhabitants of Patagonia. Geographical Review 281: 250-275.

BINFORD, L., 1981. Bones Ancient men and modern myths. Academic Press, Londres y Nueva York.

BONNICHSEN, R., 1978. Critical arguments for Pleistocene artifacts from the Old Crow Basin, Yukon: A preliminary statement. En Early Man in America, A. L. Bryan (Ed.), pp. 102-118, Occasional Papers 1, Department of Anthropology, University of Alberta.

BORDE, J., 1966. Les Andes de Santiago et leur Avant-Pays. Étude de Geomorphologie. Tesis doctoral, Union Française D'Impression, París.

BRUGGEN, J., 1950. Fundamentos de la geología de Chile. Instituto Geográfico Militar, Santiago.

BROECKER, W., 1965. Isotope geochemistry and the Pleistocene climate record. The Quaternary of the United States. VII Congress of INQUA, Wright and Frey Editors, Boulder.

CANBY, 1979. National Geographic.

CASAMIQUELA, R., 1969. Catalogación crítica de algunos vertebrados fósiles chilenos. I. Los ciervos. La presencia de Antifer (= ¿Blastocerus?) en el Pleistoceno Superior. Anales de la Academia Chilena de Ciencias Naturales 52 (31), Santiago.

-1969-70. Primeros documentos de la paleontología de vertebrados para un esquema estratigráfico y zoogeográfico del Pleistoceno de Chile. Boletín de Prehistoria de Chile $2(2-3)$.

—1976. Los vertebrados fósiles de Tagua Tagua, Primer Congreso Geológico Chileno, pp. 87-102, Santiago.

CASAMIQUELA, R., J. MONTANE y R. SANTANA, 1967. Convivencia del hombre con el mastodonte en Chile Central. Noticias sobre las investigaciones en la laguna de Tagua Tagua. Noticiario Mensual del Museo Nacional de Historia Natural 132: 1-5.

CECIONI, G. y G.WESTERMANN, 1968. The TriassicJurassic marine transition of coastal Central Chile. Pacific Geology I.

COVACEVICH, V., 1971. Los moluscos pleistocénicos y holocénicos de San Vicente de Tagua Tagua. Memoria para optar al título de Geólogo, Departamento de Geología, Universidad de Chile, Santiago.

DARWIN, C., 1882. Naturalist's voyage round the world. John Murray, Albermarle Street, Londres.

DEEVEY, E., 1960. Paleolimnology and climate. En Climatic change. Evidence, causes and effects, H. Shapley (Ed.). Harvard University Press, Cambridge.
DOMEYKO, I., 1868. Algunas palabras sobre el terreno en que se hallan huesos de mastodontes en Chile. Anales de la Universidad de Chile, Santiago.

DOYEL, W., R. DINGMAN y O. CASTILLO, 1964. Hydrogeology of the Santiago Area, Chile, U.S. Geological Survey, Professional Paper, Article 169.

DURAN, E., 1980. Tagua Tagua II, nivel de 6130 años. Descripción y relaciones. Boletín del Museo Nacional de Historia Natural 37: 75-86.

FLINT, R., 1957. Glacial and Pleistocene geology. John Wiley Sons Inc., Nueva York.

-1965. Introductions: Historical perspectives. The Quaternary of the United States. VII Congress of INQUA. Wright and Frey Editors, Boulder.

FUENZALIDA, P., 1965. Clima. En Geografía económica de Chile. Corfo, Texto refundido, cap. IV, Santiago.

-1966. Climatología. En Geografía económica de Chile. Corfo, Primer Apéndice, cap. III, Santiago.

FUENZALIDA, V., H., 1965. Biogeografía. En Geografía económica de Chile. Corfo. Texto refundido, cap. VII, Santiago.

GAY, C., 1848. Historia física y política de Chile. Zoología, Imprenta de Maulde y Renou, Louvre, París.

—1854. Atlas de la historia física y política de Chile. Zoología. París.

GONZALEZ-BONORINO, F. y M. TERUGGI, 1952. Léxico sedimentológico. Instituto Nacional de Investigación de las Ciencias Naturales, Imprenta Coni, Buenos Aires.

GUNKEL, H., 1967. De cómo el Abate Molina vio y describió los lagos chilenos. Boletín de la Universidad de Chile 80-81.

HESSE, R., W. ALLEN y K. SCHMIDT, 1966. Ecological animal geography, $2^{\mathrm{a}}$ edición. John Wiley Sons Inc., Londres y Nueva York.

HEUSSER, C., 1960. Late-Pleistocene environments of the Laguna de San Rafael Area, Chile. The Geographical Review L (4).

-1961. Some comparisons between climatic changes in Northwestern North American and Patagonia, Annals of the New York Academy of Sciences 95, article 1.

-1966a. Late-Pleistocene pollen diagrams from the Province of Llanquihue, Southern Chile. Proceeding of the American Philosophical Society 110 (4).

_ 1966b. Polar hemispheric correlation: Palynological evidence from Chile and the Pacific north-west of America. Proceeding of the International Symposium held at Imperial College. Londres. 
1983. Quaternary pollen record from Laguna de Tagua Tagua, Chile. Science 219: 1469-1432.

HUTCHINSON, E., 1957. A treatise on limnology, vol. 1. Geography, physics and chemistry. John Wiley Sons Inc. Londres y Nueva York.

IRVING., W. N. y C. R. HARRINGTON, 1973. Upper Pleistocene radiocarbon. Date artifacts from the Northern Yukon. Science 179 (4071): 335-340.

KARZULOVIC, J., 1958. Sedimentos cuaternarios y aguas subterráneas en la cuenca de Santiago. Publicación del Instituto de Geología 10.

-1960. Características de los depósitos de cenizas volcánicas de Chile Central. Informaciones Geográficas, Santiago.

LATCHAM, R., 1929. Los mastodontes chilenos. Revista de Educación 6.

MARTINEZ, R. y R. OSORIO, 1963. Consideraciones preliminares sobre la presencia de carófitas fósiles en la Formación Colimapu. Revista Minerales 82.

MONTANE, J., 1967. Investigaciones interdisciplinarias en la ex laguna Tagua Tagua, provincia de O'Higgins, Chile. Anales de la Academia Chilena de Ciencias Naturales 52 (30).

— 1968a. Primera fecha radiocarbónica de Tagua Tagua. Noticiario Mensual del Museo Nacional de Historia Natural XII (139).

_ 1968b. Paleo-indian remains from laguna de Tagua Tagua. Central Chile. Science 161.

-1969. Fechado del nivel superior de Tagua Tagua, Noticiario Mensual del Museo Nacional de Historia Natural XIV (161).

- 1976. El paleoindio en Chile. Actas del XLI Congreso Internacional de Americanistas, vol. 3, pp. 492-497, México D.F. (1974).

MONTANE, J. y R. BAHAMONDES, 1973. Un nuevo sitio paleoindio en la provincia de Coquimbo, Chile. Publicaciones del Museo Arqueológico de La Serena, Boletín 15: 215-222.

MORRISON, R., 1965a. Lake Bonneville: Quaternary stratigraphy of eastern Jordan Valley, South of Salt Lake City, Utah. Geological Survey Professional Paper 477, Washington D.C.

— 1965b. Quaternary geology of the Great Basin. The Quaternary of the United States VII Congress of INQUA. Wright and Frey Editor, Boulder.

-1969. The Pleistocene-Holocene boundary. Geologie en Mijnbouw 48 (4).

MOSTNY, G., 1968a. Association of human industries with pleistocene fauna in Central Chile. Current Anthropology 9: 2-3.

—1968b. Carbon 14. Dating Tagua Tagua material. Current Anthropology 9: 544.
MUÑOZ-CRISTI, J., 1942. Rasgos generales de la constitución geológica de la cordillera de la Costa, especialmente en la provincia de Coquimbo. Anales del Primer Congreso Panamericano de Ingeniería de Minas y Geología, vol. 2. Santiago.

NUÑEZ, L., 1983a. Paleoindio y Arcaico en Chile: Diversidad, secuencia y procesos, Ediciones Cuicuilco, Instituto de Antropología e Historia, México D.F.

- 1983b. Paleoindian and archaic cultural periods in the arid and semiarid regions of Northern Chile. Advances in world archaeology vol. 2, pp. 161-203. Academic Press, Inc.

NUÑEZ, L., J. VARELA y R. CASAMIQUELA, 1982. Ocupación paleoindia en Quereo (IV región): Reconstrucción multidisciplinaria en el territorio semiárido de Chile. Boletín del Museo Arqueológico de La Serena, pp. 32-67.

—1983. Ocupación paleoindia en Quereo: Reconstrucción multidisciplinaria en el territorio semiárido de Chile. Universidad del Norte, Antofagasta.

OLAUSSON, E., 1969. On the Würm-Flandrian boundary in deep-sea cores. Geologie en Mijnbouw 48 (3).

OLIVER SCHNEIDER, C., 1926. Lista preliminar de los mamíferos fósiles de Chile. Revista Chilena de Historia Natural.

- 1927. Las condiciones biológicas de la fauna vertebrada de Chile en la era cenozoica. Boletín de la Sociedad de Biología de Concepción 1 (1-2).

OSORIO, R. y S. COVACEVICH, 1983. Informe sobre microvertebrados en quebrada Quereo. En Ocupación paleoindia en Quereo: Reconstrucción multidisciplinaria en el territorio semiárido de Chile, L. Núñez, J. Varela y R. Casamiquela (Eds.). Universidad del Norte, Antofagasta.

PALMA, J., 1969. El sitio de Tagua Tagua en el ámbito paleoamericano. Actas $V$ Congreso Nacional de Arqueología, La Serena.

PASKOFF, R., 1970. Recherches geomorphologiques dans le Chili semi-aride, Bicaye Freres Impremeurs, Bordeaux.

PINO, M. y J. VARELA, 1977. Aplicación del método de datación por hidratación de obsidiana al sitio arqueológico de laguna de Tagua Tagua, provincia de O'Higgins. Actas del VII Congreso de Arqueología Chilena, vol. I, pp. 25-52, Ediciones Kultrun, Santiago.

POLANSKI. J., 1962. Estratigrafía, neotectónica y geomorfología del Pleistoceno pedemontano entre los ríos Diamante y Mendoza. Revista de la Asociación Geológica Argentina 3-4.

REDON, J. y G. ESPINOZA, 1969 Ms. Informe preliminar sobre las diatomeas constituyentes de los trípolis de San Vicente de Tagua Tagua, Laboratorio de Botánica, Universidad de Chile, Valparaíso.

SANTANA, R., 1968. Les Andes de Santiago et leur avantpays, por Jean Borde. Revista Geográfica 69. 
1971. Les cendres volcaniques de la vallée du CachapoalRapel (Chili). Cahiers de Geographie de Quebec XV (35), $\mathrm{n}^{\mathrm{o}}$ Special Amérique Latine.

SEGERSTROM, K., Q. CASTILLO y E. FALCON, 1964. Quaternary mudflow deposits near Santiago, Chile. U.S. Geological Survey, Professional Paper, article 152.

STANFORD, D., 1978. Scientist test ice age tool on elephant's carcass. The New York Times, monday march 20.

STERN, C., H. AMINI, R. CHARRIER, E. GODOY, F. HERVE y J. VARELA, 1984. Petrochemistry and age of rhyolitic pyroclastic flows wich occur along the drainage valleys of the río Maipo and río Cachapoal (Chile) and the río Yaucha and río Papagayos (Argentina), Revista Geológica de Chile 23: $39-52$.

STIEFEL, J., 1965a. Lahares glaciovolcánicos recientes y depósitos comparables del Pleistoceno chileno. Resumen 10, Sociedad Geológica de Chile.

_ 1965b. Sedimentary reconnaissance of some Quaternary deposits of Central and Southern Chile. Means of correlation of Quaternary sucessions, Proceeding VII Congress Int. INQUA, vol. 8, University of Utah Press, Salt Lake City.

SUNDT, L., 1903. Resto de un mastodonte encontrado cerca de Los Vilos. Anales de la Universidad de Chile CXII-CXIII,: 555-560.

VAN EYSINGA, F., 1981. Geological time table. $3^{\text {era }}$ Edición. Elsevier Publishing Co., Netherland.
VARELA, J., 1976a. Geología del cuaternario de la laguna de Tagua Tagua (prov. de O'Higgins). Actas del I Congreso Geológico, pp. 81-112. Santiago.

—1976b. Estudio estratigráfico-sedimentológico de los depósitos de laguna de Tagua Tagua, provincia de O'Higgins. Memoria para optar al Título de Geólogo, Departamento de Geología, Universidad de Chile, Santiago.

-1979. Geología del Cuaternario de la región de quebrada Quereo, Los Vilos, prov. de Choapa, IV región, Chile. Actas II Congreso Geológico Chileno de Geología, vol. 3. Imprenta IIG, Arica.

— 1981. Geología del Cuaternario del área de Los Vilos-Ensenada El Negro (IV región) y su relación con la existencia del bosque "relicto" de quebrada Quereo. Revista Comunicaciones 33: 17-30.

VICENTE, J. C., 1972. Apercu sur l'organisation e l'evolution des Andes argentino-chiliennes centrales au paralléle de l'Aconcagua, Congreso Geológico Internacional 24 Ses., Section 3, Montreal.

VILLAGRAN, C., 1983. Informe preliminar de la madera y polen subfósil contenidos en los perfiles de Quereo, Los Vilos, prov. de Choapa. Ocupación paleoindia en Quereo, pp. 103-106. Universidad del Norte, Antofagasta, Chile.

ZEUNER, F. E., 1956. Geocronología. La datación del pasado. Ediciones Omega, Barcelona. 
